\title{
The conduction velocity-potassium relationship in the heart is modulated by sodium and calcium
}

\author{
D. Ryan King ${ }^{1,2} \cdot$ Michael Entz II ${ }^{2,3} \cdot$ Grace A. Blair $^{1,2} \cdot \operatorname{lan}$ Crandell ${ }^{4} \cdot$ Alexandra L. Hanlon ${ }^{4} \cdot$ Joyce Lin ${ }^{5}$. \\ Gregory S. Hoeker ${ }^{2} \cdot$ Steven Poelzing ${ }^{1,2,3,6} \mathbb{B}$
}

Received: 10 November 2020 / Revised: 28 January 2021 / Accepted: 4 February 2021 / Published online: 4 March 2021

(C) The Author(s) 2021

\begin{abstract}
The relationship between cardiac conduction velocity $(\mathrm{CV})$ and extracellular potassium $\left(\mathrm{K}^{+}\right)$is biphasic, with modest hyperkalemia increasing CV and severe hyperkalemia slowing CV. Recent studies from our group suggest that elevating extracellular sodium $\left(\mathrm{Na}^{+}\right)$and calcium $\left(\mathrm{Ca}^{2+}\right)$ can enhance $\mathrm{CV}$ by an extracellular pathway parallel to gap junctional coupling (GJC) called ephaptic coupling that can occur in the gap junction adjacent perinexus. However, it remains unknown whether these same interventions modulate $\mathrm{CV}$ as a function of $\mathrm{K}^{+}$. We hypothesize that $\mathrm{Na}^{+}, \mathrm{Ca}^{2+}$, and GJC can attenuate conduction slowing consequent to severe hyperkalemia. Elevating $\mathrm{Ca}^{2+}$ from 1.25 to $2.00 \mathrm{mM}$ significantly narrowed perinexal width measured by transmission electron microscopy. Optically mapped, Langendorff-perfused guinea pig hearts perfused with increasing $\mathrm{K}^{+}$revealed the expected biphasic $\mathrm{CV}-\mathrm{K}^{+}$relationship during perfusion with different $\mathrm{Na}^{+}$and $\mathrm{Ca}^{2+}$ concentrations. Neither elevating $\mathrm{Na}^{+}$nor $\mathrm{Ca}^{2+}$ alone consistently modulated the positive slope of $\mathrm{CV}-\mathrm{K}^{+}$or conduction slowing at $10-\mathrm{mM} \mathrm{K}^{+}$; however, combined $\mathrm{Na}^{+}$and $\mathrm{Ca}^{2+}$ elevation significantly mitigated conduction slowing at $10-\mathrm{mM} \mathrm{K}{ }^{+}$. Pharmacologic GJC inhibition with $30-\mu \mathrm{M}$ carbenoxolone slowed $\mathrm{CV}$ without changing the shape of $\mathrm{CV}-\mathrm{K}^{+}$curves. A computational model of $\mathrm{CV}$ predicted that elevating $\mathrm{Na}^{+}$and narrowing clefts between myocytes, as occur with perinexal narrowing, reduces the positive and negative slopes of the $\mathrm{CV}-\mathrm{K}^{+}$relationship but do not support a primary role of GJC or sodium channel conductance. These data demonstrate that combinatorial effects of $\mathrm{Na}^{+}$and $\mathrm{Ca}^{2+}$ differentially modulate conduction during hyperkalemia, and enhancing determinants of ephaptic coupling may attenuate conduction changes in a variety of physiologic conditions.
\end{abstract}

Keywords Hyperkalemia $\cdot$ Sodium $\cdot$ Calcium $\cdot$ Cardiac Electrophysiology $\cdot$ Langendorff

\section{Introduction}

Coordinated electrical activity in the heart is facilitated through a sequence of transmembrane ion exchange events governed by channels, pumps, and exchangers [4]. A major determinant of the speed of cell-to-cell electrical action potential propagation (conduction velocity; $\mathrm{CV}$ ) in cardiac tissue is the inward sodium current $\left(I_{\mathrm{Na}}\right)[8,4]$. It is well appreciated that $I_{\mathrm{Na}}$ is modified by changes in the resting membrane potential (RMP) of the cardiomyocyte [32, 74]. During diastole,

This article is part of the special issue on Calcium Signal Dynamics in Cardiac Myocytes and Fibroblasts: Mechanisms in Pflügers ArchivEuropean Journal of Physiology

Steven Poelzing

poelzing@vtc.vt.edu

1 Translational Biology, Medicine, and Health Graduate Program, Virginia Polytechnic Institute and State University, Blacksburg, VA, USA

2 Center for Heart and Reparative Medicine Research, Fralin Biomedical Research Institute at Virginia Tech Carilion, Roanoke, VA, USA
3 Department of Biomedical Engineering and Mechanics, Virginia Polytechnic Institute and State University, Blacksburg, VA, USA

4 Center for Biostatistics and Health Data Science, Virginia Polytechnic Institute and State University, Roanoke, VA, USA

5 Department of Mathematics, California Polytechnic State University, San Luis Obispo, CA, USA

6 School of Medicine, Virginia Tech Carilion, Roanoke, VA, USA 
RMP is primarily maintained by potassium currents, [33, 31] and changing extracellular potassium $\left(\mathrm{K}^{+}\right)$concentration will directly alter the RMP. Depending on RMP, sodium $\left(\mathrm{Na}^{+}\right)$ channel availability and $I_{\mathrm{Na}}$ can also be modulated.

Given the dense expression of the voltage gated sodium channel Nav1.5 in the intercalated disc [55] and more specifically in the gap junction (GJ) adjacent perinexus [57, 70], recent evidence suggests that reducing $I_{\mathrm{Na}}$ exacerbates conduction slowing when intercellular separation in the perinexus is widened by altering an electrical field coupling (i.e., ephaptic coupling, EpC) pathway parallel to gap junctional coupling (GJC). In brief, EpC posits that extracellular potential perturbations in shared clefts between cells can transactivate apposing voltage-gated ion channels. Computational models demonstrate $\mathrm{EpC}$ can be modified by changing the cleft width between neighboring cardiomyocytes, particularly in the GJ adjacent perinexus $[58,23]$, and by altering ionic concentrations within intercellular clefts $[63,38,48,40,66,73]$. However, it remains unknown how EpC may modulate the relationship between $\mathrm{CV}$ and extracellular $\mathrm{K}^{+}$.

In guinea pigs, both experimental and computational models demonstrate that the $\mathrm{CV}-\mathrm{K}^{+}$relationship is biphasic. $[32,52,35] \mathrm{CV}$ is positively correlated with $\mathrm{K}^{+}$until approximately $8 \mathrm{mM}$ by a mechanism of reducing the potential difference between RMP and $\mathrm{Na}^{+}$channel activation threshold (i.e., increasing excitability) $[32,61]$. Once $\mathrm{K}^{+}$increases to the point that RMP exceeds $\mathrm{Na}^{+}$channel activation threshold, $\mathrm{CV}$ will subsequently decrease as the number of $\mathrm{Na}^{+}$channels in the inactive state increases [25, 74].

It is important to note here that GJC, and not $\mathrm{EpC}$, is still considered the principal mediator of electrical propagation between cardiomyocytes. This is important because GJC may also modulate the relationship between CV and $\mathrm{K}^{+}$. Though, the historic relationship between $\mathrm{CV}$ and GJC, particularly mediated by the principal ventricular GJ protein connexin 43 (Cx43), is not straightforward. While GJ functional expression should correlate with CV [10], our previous work documented the myriad of CV responses associated with the Cx43 heterozygous knockout mouse and demonstrated that electrolyte composition in crystalloid perfusates can significantly modulate CV slowing in hearts with genetically reduced Cx43 expression [18, 14, 17]. The mechanism by which GJ-dependent CV can be modulated by electrolyte composition is via EpC, because GJC alters intracellular potentials while EpC modulates both extracellular potentials and extracellular ion concentrations. Together, dynamic changes in transmembrane and reversal potentials within intercalated disc nanodomains interact to rapidly propagate the action potential wave front, while simultaneously acting in a negative feedback mechanism (self-attenuation) to produce often invariant conduction until one form of coupling is altered dramatically enough to overwhelm the other mechanism and slow conduction [19].

Recent evidence supports EpC as a mechanism that modulates cardiac electrophysiology in response to GJ uncoupling $[68,18,11,14]$, reduced inward rectifier potassium current [71], reduced sodium channel beta subunit adhesion [69], sodium channel gain-of-function [19, 50], atrial fibrillation [56], inflammatory cytokines $[15,45]$, and ischemia $[16,27]$. With regard to this last case, ischemia is often associated with elevated $\mathrm{K}^{+}$, leading us to hypothesize that the $\mathrm{CV}-\mathrm{K}^{+}$relationship can also be altered via electrolyte modification. More specifically, we hypothesize that increasing perfusate $\mathrm{Na}^{+}$will increase the sodium reversal potential and therefore peak $I_{\mathrm{Na}}$, and increasing calcium $\left(\mathrm{Ca}^{2+}\right)$ will, among other things, narrow or attenuate perinexal expansion [14, 16, 27]. This study also tests whether GJC is a modulator of the $\mathrm{CV}-\mathrm{K}^{+}$relationship in the context of altered $\mathrm{Na}^{+}$and $\mathrm{Ca}^{2+}$. Our data demonstrate that combinatorial effects of $\mathrm{Na}^{+}$and $\mathrm{Ca}^{2+}$ differentially preserve $\mathrm{CV}$ during hyperkalemia and suggest that enhancing determinants of $\mathrm{EpC}$ may attenuate $\mathrm{CV}$ changes in a variety of physiologically relevant conditions.

\section{Methods}

All studies were designed to adhere to the guidelines set forth by the Institutional Animal Care and Use Committee at Virginia Polytechnic Institute and State University and NIH Guide for the Care and Usage of Laboratory Animals.

\section{Langendorff perfusion}

Adult male Hartley albino guinea pigs (Hilltop, Scottdale, PA, $n=85,800-1,200 \mathrm{~g}, 14-16$ months old) were anesthetized using isofluorane ( $4 \%$ in $\mathrm{O}_{2}$ ). After loss of peripheral stimuli response, the heart was excised and rapidly cannulated $(<4$ minutes) for retrograde perfusion in a 3-D printed PLA bath [12]. The lab standard crystalloid perfusate contained (in $\mathrm{mM}$ ) $140 \mathrm{NaCl}, 5.0 \mathrm{NaOH}, 4.56 \mathrm{KCl}, 1.25 \mathrm{CaCl}_{2} \cdot 2 \mathrm{H}_{2} \mathrm{O}, 5.5 \mathrm{dex}-$ trose, $0.7 \mathrm{MgCl}_{2} \cdot 6 \mathrm{H}_{2} \mathrm{O}$, and $10 \mathrm{HEPES}$. The perfusate was equilibrated to a $\mathrm{pH}$ of 7.4 using $\mathrm{NaOH}$ or $\mathrm{HCl}$, as necessary, at $37.0^{\circ} \mathrm{C}$. Perfusion occurred at a constant flow to maintain coronary pressure between 40 and $60 \mathrm{mmHg}$. Atria were removed to inhibit competitive stimulation, and ventricles were paced with an $\mathrm{AgCl}$ wire placed on the anterior left ventricular epicardium; the ground electrode was placed within the superfusion bath. Stimulation strength was set at 1.5 times the excitation threshold with 5-ms pulse duration and delivered at a basic cycle length of $300 \mathrm{~ms}$.

Using the lab standard perfusate as a baseline, $\mathrm{Na}^{+}, \mathrm{Ca}^{2+}$, and $\mathrm{K}^{+}$were varied. Specifically, $\mathrm{Na}^{+}$was changed from 145 to $155 \mathrm{mM}$, and $\mathrm{Ca}^{2+}$ was changed from 1.25 to $2.0 \mathrm{mM}$. For 
each individual experiment, $\mathrm{Na}^{+}$and $\mathrm{Ca}^{+}$were held constant, while $\mathrm{K}^{+}$was varied between four concentrations (4.6, 6.4, 8.0 , and $10 \mathrm{mM})$. In total, there were 16 unique combinations of $\mathrm{Na}^{+}, \mathrm{Ca}^{2+}$, and $\mathrm{K}^{+}$used in this study,

GJs were inhibited by perfusion of the nonspecific GJ uncoupler carbenoxolone (CBX, $30 \mu \mathrm{M})$, which has previously been shown to decrease CV [20]. For experiments containing $\mathrm{CBX}$, the first measurements were taken after 15 minutes of perfusion, as time control studies indicated CV reached steady state within that timeframe (data not shown). Subsequent measurements were made at 10-minute intervals.

\section{Electrocardiography}

A volume-conducted bath electrocardiogram (ECG) was recorded using $\mathrm{AgCl}$ electrodes, collected at $1 \mathrm{kHz}$. Electrodes were placed on both sides of the ventricles, with the ground placed at the rear of the bath. Asystole was defined as a lack of discernable ECG at any point during perfusion.

\section{Transmission electron microscopy}

Tissue was sectioned into $1 \mathrm{~mm}^{3}$ cubes from the anterior left ventricular free wall $(n=5$ hearts perfused with solutions containing $1.25-\mathrm{mM} \mathrm{Ca}^{2+}$ and $n=4$ hearts perfused with 2.0-mM Ca ${ }^{2+}, 3$ tissue samples per heart and between 6 and 15 perinexal images per sample). The tissue was fixed overnight in $2.5 \%$ glutaraldehyde at $4^{\circ} \mathrm{C}$, washed and transferred to PBS, and stored at $4^{\circ} \mathrm{C}$. The tissue was processed as previously described [11]. Images of the GJ-adjacent perinexus were collected at $150,000 \times$ magnification on a transmission electron microscope (JEOL JEM1400). ImageJ (NIH) was used for manual segmentation of the perinexus. Perinexi were analyzed starting at the point directly adjacent to GJs, measuring up to $150 \mathrm{~nm}$ from the GJ plaque as previously described [11]. Changes in perinexal width $\left(W_{\mathrm{p}}\right)$ were analyzed as the average intermembrane separation at distances between 45 and $105 \mathrm{~nm}$ from the GJ plaque. The average $W_{\mathrm{P}}$ for a heart was the average $W_{\mathrm{P}}$ for every perinexi collected from that heart (between 6 and 15 perinexi per heart). Raw datapoints in Fig. 1 are the average $W_{\mathrm{P}}$ for individual hearts.

\section{Optical mapping}

Following a brief period of stabilization (15 minutes), hearts were perfused with the voltage sensitive dye di-4-ANEPPS $(7.5 \mu \mathrm{M})$ followed by a 10 -minute washout period. The electro-mechanical uncoupler 2,3-butanedione monoxime (BDM, $7.5 \mathrm{mM}$ ) was used to decrease cardiac motion. In order to further stabilize the heart for imaging, light mechanical pressure was placed on the posterior surface of the heart. The fluorophore was excited by a halogen light source (MHAB-150 W, Moritex) equipped with a fiber light guide and 520/35-nm band-pass filter (Brightline). The filtered excitation light was directed onto a dichroic mirror $(565 \mathrm{~nm}$, Chroma Technology) and reflected onto the heart via epi-illumination. Emitted light was collected via a tandem lens system and transmitted through a 610-nm long-pass filter (Andover Corp.) before detection by a MiCam Ultima Ltype CMOS camera (SciMedia: $100 \times 100$ pixels, field of view-15.9 × $15.9 \mathrm{~mm})$. Baseline optical action potentials were recorded at a $1-\mathrm{kHz}$ sample rate for a duration of $\sim 2$ seconds during intrinsic activity and steady-state pacing at a 300-ms cycle length.

Cardiac CV was calculated as previously described [6, 16]. Briefly, activation time for each pixel was determined as the maximum rate of optical action potential rise. CV was quantified in two directions, longitudinal $\left(\mathrm{CV}_{\mathrm{L}}\right)$ and transverse $\left(\mathrm{CV}_{\mathrm{T}}\right)$. Conduction in each direction was quantified by selecting vectors within five pixels and an angle of $\pm 8^{\circ}$ from a user-defined direction of longitudinal (fastest) and transverse (slowest) propagation. Conduction vectors immediately adjacent to the pacing site were excluded to reduce pacing artifacts. Data are presented herein as representative isochrone maps with 3-ms time steps.

\section{Statistical analysis}

Statistical analyses were performed in GraphPad Prism 7 and $\mathrm{R}$ version 3.6.0. Within $\mathrm{R}$, mixed effect models were fit using the Ime4 library [5]. For all data, $p<0.05$ was considered statistically significant. Data from a total of 85 hearts are reported in this study. Specific $n$ values for each experimental group are included in the figure legends. All summary data are presented as mean \pm standard error unless otherwise noted. Details of specific statistical analyses used are included in figure legends.

Experiments were performed in a blinded and randomized fashion. The experimentalist was blinded to the $\mathrm{Na}^{+}, \mathrm{Ca}^{2+}$, and $\mathrm{K}^{+}$concentrations of all perfusion fluids. Likewise, the order of the blinded perfusion solutions was randomized such that neither the experimentalist nor data analyst had knowledge of the perfusate contents until the conclusion of all analyses.

\section{Computational simulations}

To compare the experimental data with a computational model, we used equations that incorporated the importance of the junctional cleft, as done previously [40, 41]. Simulations were run using a strand of 50 cells, shaped like rectangular prisms, withan ionic current model that tracks ion concentrations [43]. GJs were located only on the ends of the cells, along with the majority of the fast sodium ion channels. The intracellular and extracellular current equations discretized both the intracellular and extracellular space, described previously [42], were 
integrated in time using a Crank-Nicolson scheme and integrated in space using centered finite differences. A strand was chosen for computational efficiency and with the prior assumption that the number of cell-to-cell junctions per unit length is a determinant of conduction [70]. Hence, the strand model can inform longitudinal or transverse conduction without confounding variables introduced by 2 - and 3-D models such as wave-front curvature.

Current was briefly injected into the strand to initiate an action potential, which traveled down the cable. The times at which cells in the middle of the strand depolarized were recorded to compute CV. The nominal value of GJC was 666 $\mathrm{mS} / \mathrm{cm}^{2}$, and cellular length and width were $0.01 \mathrm{~cm}$ and approximately $0.0017 \mathrm{~cm}$, respectively (6:1 ratio), and membrane capacitance was held at $1 \mu \mathrm{F} / \mathrm{cm}^{2}$. Extracellular space had a conductivity of $20 \mathrm{mS} / \mathrm{cm}$, with the lateral width of $10^{-5}$ $\mathrm{cm}$ and perinexal width of $1.5 \times 10^{-6} \mathrm{~cm}$.

\section{Results}

\section{Perinexal width}

We previously demonstrated that elevating perfusate $\mathrm{Ca}^{2+}$ can reduce perinexal width $\left(W_{\mathrm{p}}\right)$ in hearts perfused with $145-\mathrm{mM}$ $\mathrm{Na}^{+}[18,27]$. To confirm this finding when hearts are perfused with $155-\mathrm{mM} \mathrm{Na}^{+}$, we here present representative transmission electron micrographs of hearts perfused with $155-\mathrm{mM}$ $\mathrm{Na}^{+}$and either 1.25- or 2.00-mM Ca ${ }^{2+}$ (Fig. 1a). The measurements from 45 to $105 \mathrm{~nm}$ were averaged for each heart (Fig. 1b) and compared between $\mathrm{Ca}^{2+}$ concentrations. Consistent with our previous findings, increasing $\mathrm{Ca}^{2+}$ to $2.00 \mathrm{mM}$ can decrease $W_{\mathrm{p}}$ compared to $1.25-\mathrm{mM} \mathrm{Ca}^{2+}$ (Fig. 1c) $[18,27]$.

\section{Conduction velocity}

Representative isochrone maps and summary data of all $\mathrm{Na}^{+}$ and $\mathrm{Ca}^{2+}$ perfusate combinations at $4.6-\mathrm{mM} \mathrm{K}^{+}$are presented in Fig. 2a. Altering $\mathrm{Na}^{+}$and/or $\mathrm{Ca}^{2+}$ at baseline, in the presence of 4.6-mM K${ }^{+}$, does not significantly change $\mathrm{CV}_{\mathrm{T}}$ or $\mathrm{CV}_{\mathrm{L}}$, as can be seen in the summary data within Fig. $2 \mathrm{~b}$.

\section{Transverse conduction velocity}

As expected, varying $\mathrm{K}^{+}$between 4.6 and $10.0 \mathrm{mM}$ produces a biphasic response in $\mathrm{CV}_{\mathrm{T}}$ (Fig. 3; Supplemental Figure 2). Representative isochrone maps in Fig. 3a suggest certain ionic combinations increase $\mathrm{CV}$, as evidenced by fewer isochrones and colors, while other maps suggest conduction slowing. Specifically, faster $\mathrm{CV}_{\mathrm{T}}$ (supernormal conduction) is observed at $6.4-\mathrm{mM} \mathrm{K}^{+}$in hearts perfused with the $145-\mathrm{mM} \mathrm{Na}^{+} / 1.25$ $\mathrm{mM} \mathrm{Ca}^{2+}, 145-\mathrm{mM} \mathrm{Na}^{+} / 2.00-\mathrm{mM} \mathrm{Ca}^{2+}$, and $155-\mathrm{mM} \mathrm{Na}^{+} /$ $2.00-\mathrm{mM} \mathrm{Ca}^{2+}$ solutions. The $155-\mathrm{mM} \mathrm{Na}^{+} / 2.00-\mathrm{mM} \mathrm{Ca}^{2+}$ group also demonstrates faster $\mathrm{CV}_{\mathrm{T}}$ at $8.0-\mathrm{mM} \mathrm{K}^{+}$(Fig. 3b). $\mathrm{CV}_{\mathrm{T}}$ slowing with severe hyperkalemia $\left(10-\mathrm{mM} \mathrm{K}^{+}\right)$is observed in hearts perfused with three of the four solutions: 145 $\mathrm{mM} \mathrm{Na}^{+} / 1.25-\mathrm{mM} \mathrm{Ca}^{2+}, 145-\mathrm{mM} \mathrm{Na}^{+} / 2.00-\mathrm{mM} \mathrm{Ca}^{2+}$, and $155-\mathrm{mM} \mathrm{Na}^{+} / 1.25-\mathrm{mM} \mathrm{Ca}^{2+}$ solutions (Fig. 3a and b). Yet, $\mathrm{CV}_{\mathrm{T}}$ is not significantly different at $10-\mathrm{mM} \mathrm{K}^{+}$relative to 4.6$\mathrm{mM} \mathrm{K}^{+}$when hearts are perfused with $155-\mathrm{mM} \mathrm{Na}^{+} / 2.00-\mathrm{mM}$ $\mathrm{Ca}^{2+}$ (Supplemental Figure 1; Supplemental Table 1). These results suggest that the combination of elevated $\mathrm{Na}^{+}$and elevated $\mathrm{Ca}^{2+}$ can attenuate $\mathrm{CV}_{\mathrm{T}}$ slowing caused by severe hyperkalemia. We further attempted to compare the $\mathrm{CV}_{\mathrm{T}}-\mathrm{K}^{+}$ relationship across $\mathrm{Na}^{+} / \mathrm{Ca}^{2+}$ variations by comparing the datasets fit with a quadratic model (Supplemental Figure 2). Unfortunately, this approach did not reveal any statistically significant differences among curves. a

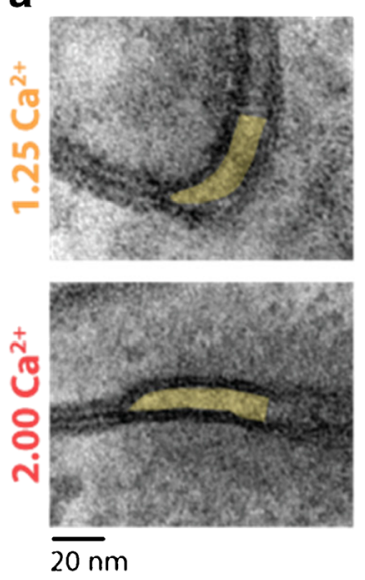

b

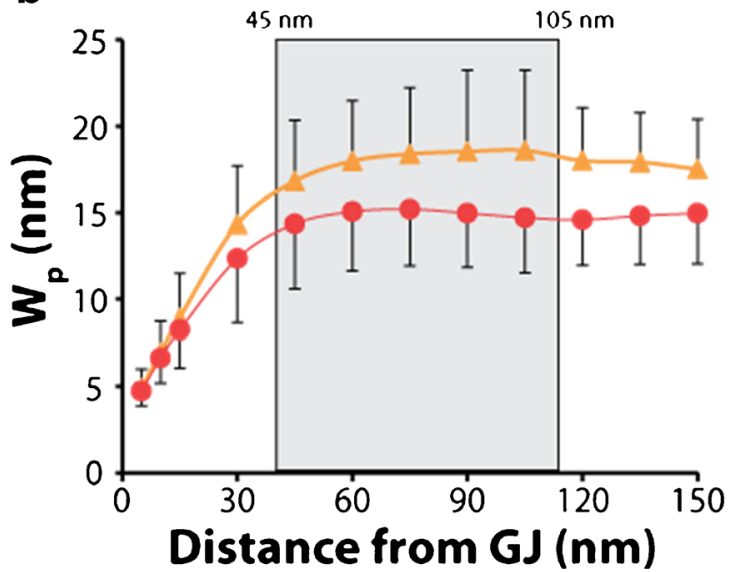

C

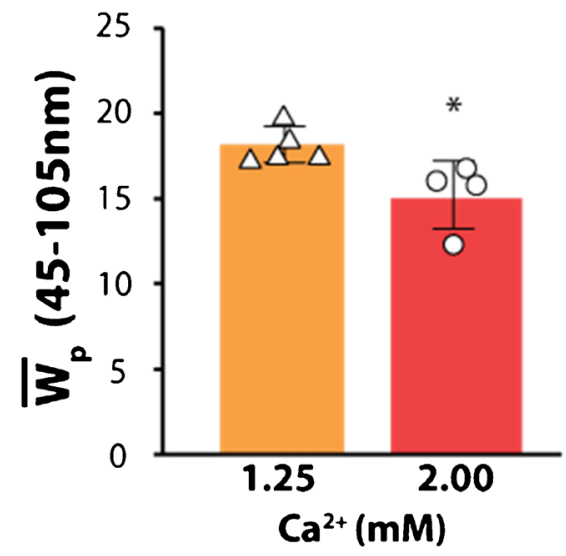

Fig. 1 Increasing $\mathrm{Ca}^{2+}$ decreases $W_{\mathrm{p}}$ in the presence of $155-\mathrm{mM} \mathrm{Na}^{+}$. (a) Representative transmission electron micrographs of perinexi with 1.25and $2.00-\mathrm{mM} \mathrm{Ca}^{2+}$, (b) $W_{\mathrm{p}}$ measurements from 0 to $150 \mathrm{~nm}$ from GJ plaque, (c) Average $W_{\mathrm{p}}$ measurements for $45-105 \mathrm{~nm}$ from GJ plaque,
$W_{\mathrm{p}}$ significantly decreased with $2.00-\mathrm{mM} \mathrm{Ca}^{2+}$. $(n=5$ hearts perfused with $1.25-\mathrm{mM} \mathrm{Ca}^{+2}$ and $n=4$ hearts with $2.00-\mathrm{mM} \mathrm{Ca}^{2+}, * p<0.05$ compared to $1.25-\mathrm{mM} \mathrm{Ca}^{2+}$ via two-tailed Student's $t$ test) 
Fig. 2 Altering $\mathrm{Na}^{+}, \mathrm{Ca}^{2+}$, or $\mathrm{Na}^{+}$ and $\mathrm{Ca}^{2+}$ does not change $\mathrm{CV}_{\mathrm{T}}$ or $\mathrm{CV}_{\mathrm{L}}$ at $4.6-\mathrm{mM} \mathrm{K}^{+}$. (a)

Representative isochrone maps for each $\mathrm{Na}^{+} / \mathrm{Ca}^{2+}$ perfusion combination. The $145-\mathrm{mM} \mathrm{Na}^{+} /$ $1.25-\mathrm{mM} \mathrm{Ca}^{2+}$ map is marked with $\mathrm{CV}_{\mathrm{T}}$ and $\mathrm{CV}_{\mathrm{L}}$ designations for visualization purposes, (b) Summary of $\mathrm{CV}_{\mathrm{T}}$ and $\mathrm{CV}_{\mathrm{L}}$ at 4.6$\mathrm{mM} \mathrm{K}^{+} . p<0.05$ denoted by *, significance determined by oneway ANOVA with Dunnett's correction for multiple comparisons. ( $n=12,14,15,15$ from left to right respectively for both $\mathrm{CV}_{\mathrm{T}}$ and $\mathrm{CV}_{\mathrm{L}}$ ) a
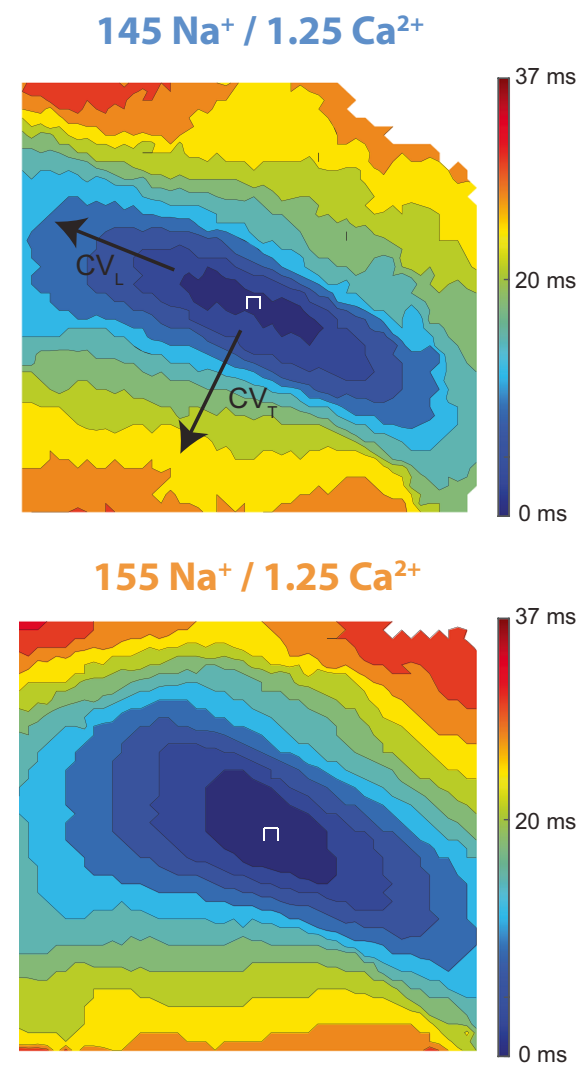

b

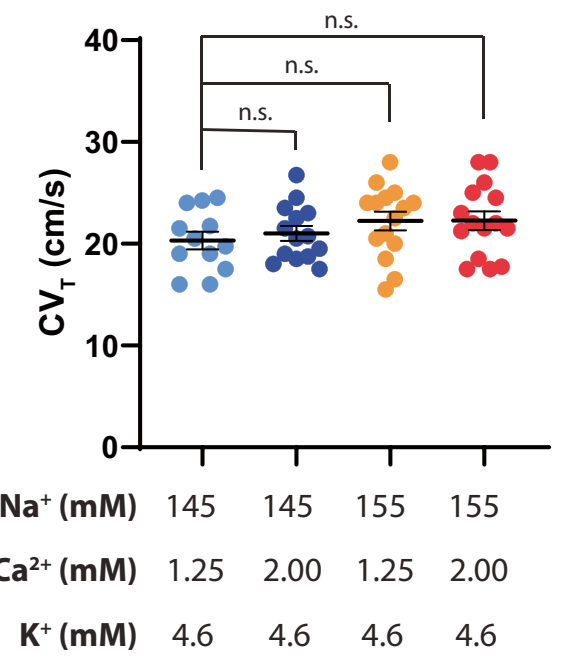

$145 \mathrm{Na}^{+} / 2.00 \mathrm{Ca}^{2+}$

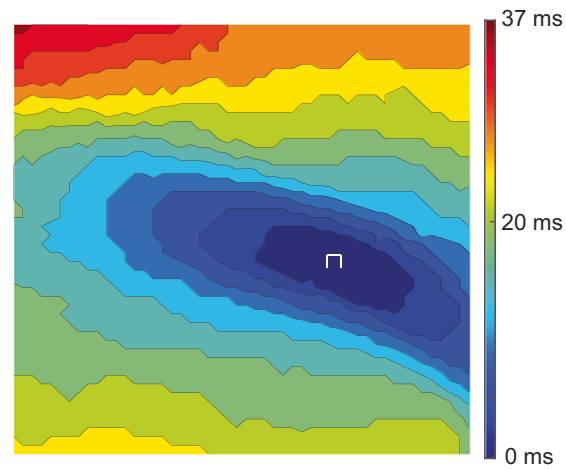

$155 \mathrm{Na}^{+} / 2.00 \mathrm{Ca}^{2+}$
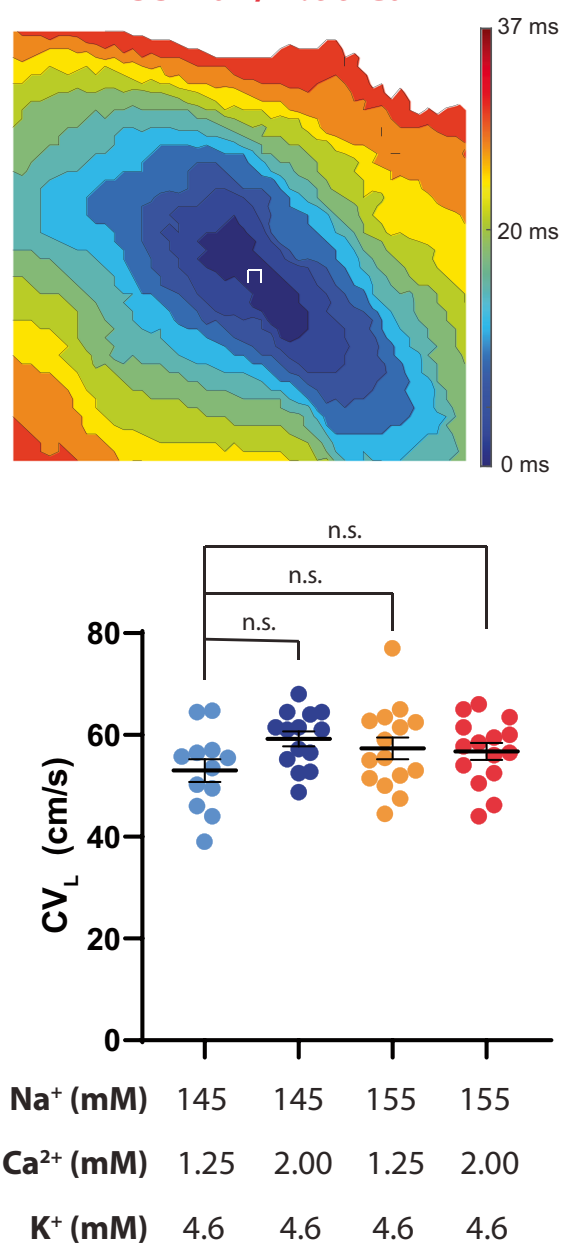

\section{Longitudinal conduction velocity}

Similar to the analysis of $\mathrm{CV}_{\mathrm{T}}$, the relationship of $\mathrm{CV}_{\mathrm{L}}$ and $\mathrm{K}^{+}$ between 4.6 and $10.0 \mathrm{mM}$ is biphasic (Fig. 3c; Supplemental Figure 2). Faster $\mathrm{CV}_{\mathrm{L}}$ is observed at $6.4-\mathrm{mM} \mathrm{K}^{+}$in hearts perfused with the $145-\mathrm{mM} \mathrm{Na}^{+} / 1.25-\mathrm{mM} \mathrm{Ca}^{2+}, 155-\mathrm{mM}$ $\mathrm{Na}^{+} / 1.25-\mathrm{mM} \mathrm{Ca}^{2+}$, and $155-\mathrm{mM} \mathrm{Na}^{+} / 2.00-\mathrm{mM} \mathrm{Ca}^{2+}$ solutions (Fig. 3c). $\mathrm{CV}_{\mathrm{L}}$ slowing with severe hyperkalemia (10-
$\mathrm{mM} \mathrm{K}^{+}$) is observed in hearts perfused with the $145-\mathrm{mM} \mathrm{Na}^{+} /$ $1.25-\mathrm{mM} \mathrm{Ca}^{2+}, 145-\mathrm{mM} \mathrm{Na}^{+} / 2.00-\mathrm{mM} \mathrm{Ca}^{2+}$, and $155-\mathrm{mM}^{-}$ $\mathrm{Na}^{+} / 1.25-\mathrm{mM} \mathrm{Ca}^{2+}$ solutions (Fig. 3c). Consistent with $\mathrm{CV}_{\mathrm{T}}, \mathrm{CV}_{\mathrm{L}}$ is not significantly different in hearts perfused with $155-\mathrm{mM} \mathrm{Na}^{+} / 2.00-\mathrm{mM} \mathrm{Ca}^{2+}$ at $10-\mathrm{mM} \mathrm{K}^{+}$relative to $4.6-\mathrm{mM}$ $\mathrm{K}^{+}$. Taken together, these results further support the finding that the combination of elevated $\mathrm{Na}^{+}$and $\mathrm{Ca}^{2+}$ can preferentially attenuate $\mathrm{CV}$ slowing caused by severe hyperkalemia. 
a
$145 \mathrm{Na}^{+}$

$1.25 \mathrm{Ca}^{2+}$
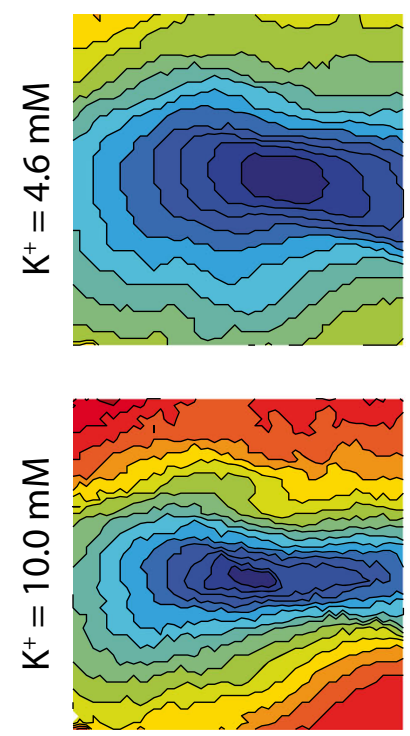

b

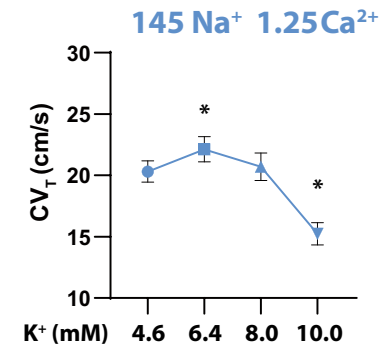

$145 \mathrm{Na}^{+}$

$2.00 \mathrm{Ca}^{2+}$
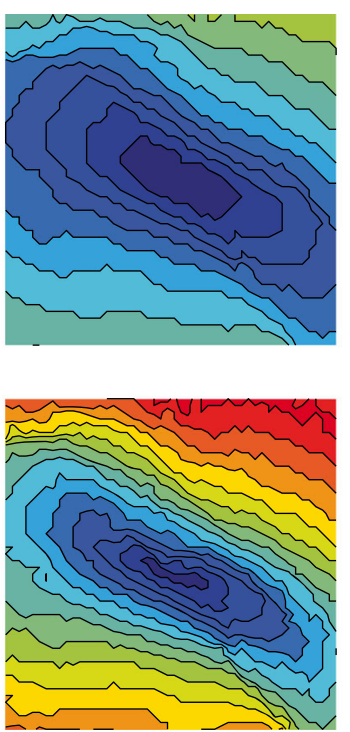

$145 \mathrm{Na}^{+} 2.00 \mathrm{Ca}^{2+}$

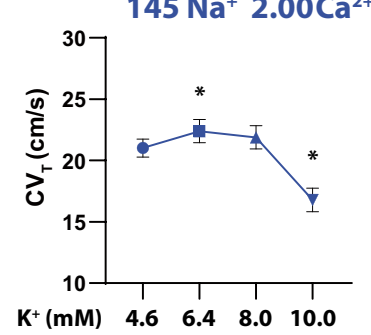

$155 \mathrm{Na}^{+}$

$1.25 \mathrm{Ca}^{2+}$
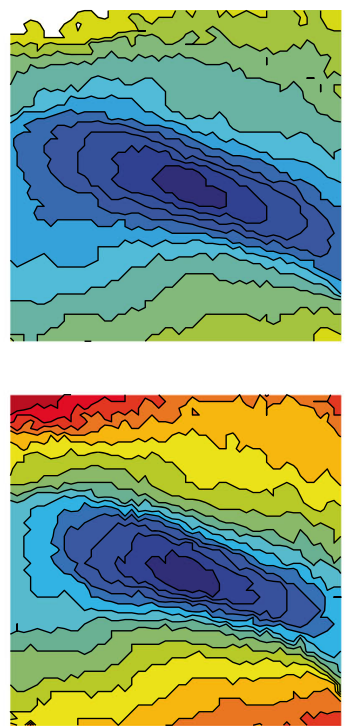

$155 \mathrm{Na}^{+}$

$2.00 \mathrm{Ca}^{2+}$
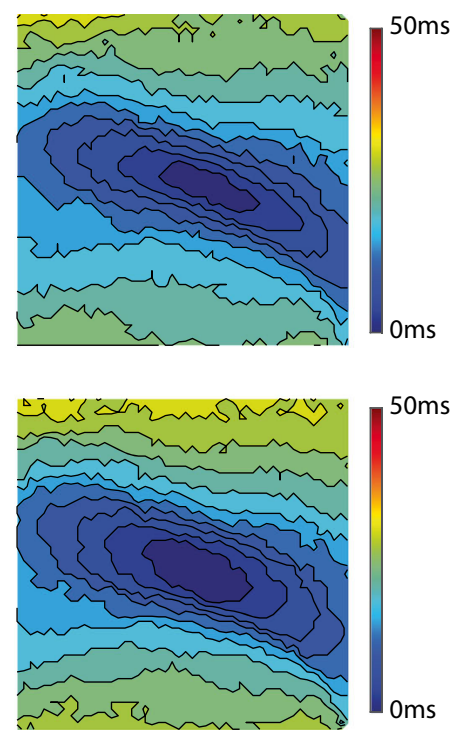

C

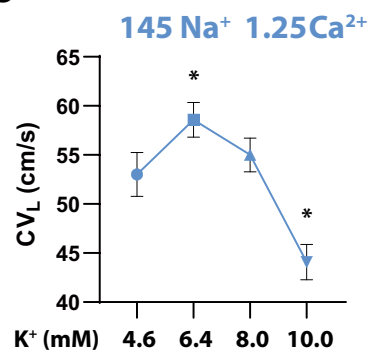

$145 \mathrm{Na}^{+} 2.00 \mathrm{Ca}^{2+}$

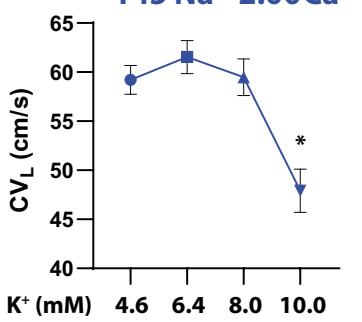

Fig. 3. Simultaneously increasing $\mathrm{Na}^{+}$and $\mathrm{Ca}^{2+}$ preserves $\mathrm{CV}_{\mathrm{T}}$ and $\mathrm{CV}_{\mathrm{L}}$ at $10.0-\mathrm{mM} \mathrm{K}^{+}$. (a) Representative isochrone maps for each $\mathrm{Na}^{+} / \mathrm{Ca}^{2+}$ perfusion combination at 4.6- and $10.0-\mathrm{mM} \mathrm{K}^{+}$, (b) Summary of $\mathrm{CV}_{\mathrm{T}}$ as a function of $\mathrm{K}^{+}$for all $\mathrm{Na}^{+}$and $\mathrm{Ca}^{2+}$ perfusion combinations, (c) Summary

\section{Incidence of asystole}

A surprising finding in the study was that incidence of asystole at $10-\mathrm{mM} \mathrm{K}^{+}$varied among the different ionic concentrations. Specifically, all hearts perfused with the $145-\mathrm{mM}$ $\mathrm{Na}^{+} / 1.25-\mathrm{mM} \mathrm{Ca}^{+}$solution develop asystole in the presence of $10-\mathrm{mM} \mathrm{K}^{+}$(Fig. 4a). Elevating $\mathrm{Ca}^{2+}$ alone does not
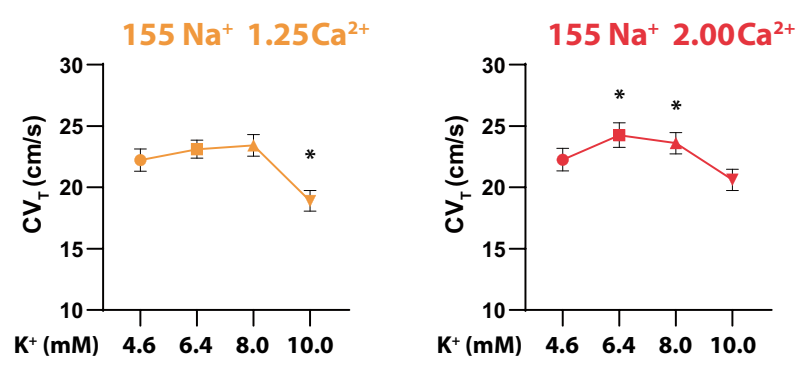

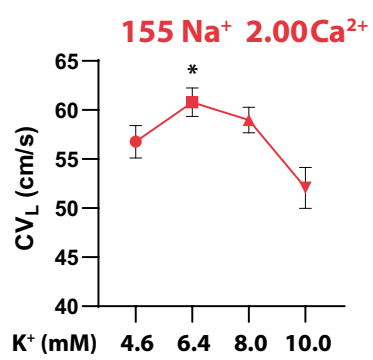

of $\mathrm{CV}_{\mathrm{L}}$ as a function of $\mathrm{K}^{+}$for all $\mathrm{Na}^{+}$and $\mathrm{Ca}^{2+}$ perfusion combinations. $p$ $<0.05$ denoted by ${ }^{*}$, significance determined by one-way ANOVA with Dunnett's correction for multiple comparisons $(n=12,14,15,15$ from left to right, respectively).

significantly reduce the incidence of asystole $\left(145-\mathrm{mM} \mathrm{Na}^{+} /\right.$ $\left.2.00-\mathrm{mM} \mathrm{Ca}^{2+}\right)$. However, asystole is significantly reduced in hearts perfused with $155-\mathrm{mM} \mathrm{Na}^{+}$with or without elevated $\mathrm{Ca}^{2+}$.

To further probe the mechanism of intrinsic rhythm preservation with elevated $\mathrm{Na}^{+}$, we pharmacologically inhibited GJC with CBX $(30 \mu \mathrm{M})$. Interestingly, CBX significantly 


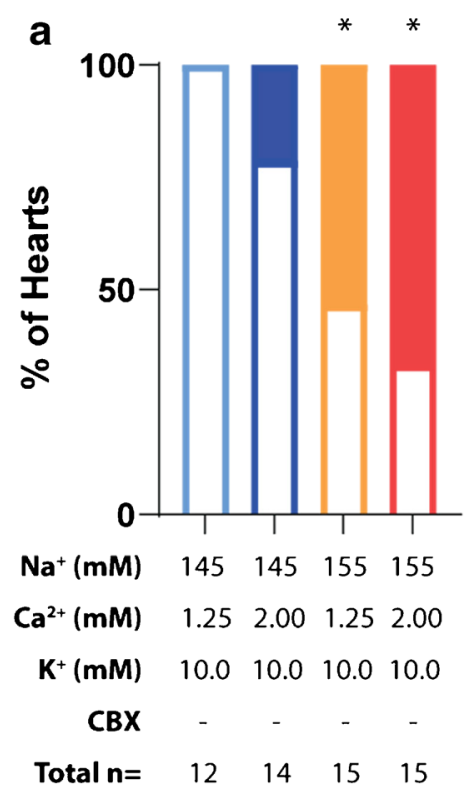

Fig. 4 Incidence of asystole during $10.0-\mathrm{mM} \mathrm{K}^{+}$perfusion. (a) Elevating perfusate $\mathrm{Na}^{+}$significantly increases the preservation of intrinsic rhythm at $10.0-\mathrm{mM} \mathrm{K}^{+}$perfusion (significance determined by Fisher's exact test; * denotes $p<0.05$ as compared to $145-\mathrm{mM} \mathrm{Na}^{+}, 1.25-\mathrm{mM} \mathrm{Ca}^{2+}, 10.0-$ $\mathrm{mM} \mathrm{K}{ }^{+}$perfusate group), (b) Inhibiting GJs with CBX $(30 \mu \mathrm{M})$ significantly increases the preservation of intrinsic rhythm in the presence of

reduces the development of asystole at $10-\mathrm{mM} \mathrm{K}^{+}$in the 145 $\mathrm{mM} \mathrm{Na}{ }^{+}$perfusion groups but does not further reduce the incidence of asystole in the $155-\mathrm{mM} \mathrm{Na}^{+}$perfusion groups (Fig. 4b).

\section{Carbenoxolone}

We find that $\mathrm{CBX}$ reduces $\mathrm{CV}$ regardless of $\mathrm{Na}^{+}, \mathrm{Ca}^{2+}$, or $\mathrm{K}^{+}$ concentrations, consistent with previous findings [20]. In summary, CV values in Fig. 5a are significantly reduced at $4.6-\mathrm{mM}$ $\mathrm{K}^{+}$with CBX relative to measured values in Fig. 3 ( $p<0.05$ for all comparisons), but once again the combinations of $\mathrm{Na}^{+}$and $\mathrm{Ca}^{2+}$ do not produce significant differences in $\mathrm{CV}_{\mathrm{T}}$ (Fig. 5b) or $\mathrm{CV}_{\mathrm{L}}$ (Fig. 5c) at 4.6- $\mathrm{mM} \mathrm{K}^{+}$with $\mathrm{CBX}$. Interestingly, the expected $\mathrm{CV}$ increase between 4.6- and 8- $\mathrm{mM} \mathrm{K}^{+}$is not observed with $\mathrm{CBX}$ with any $\mathrm{Na}^{+}$or $\mathrm{Ca}^{2+}$ combination, and a post hoc comparison of the $\mathrm{CV}$ change between 4.6- $\mathrm{mM}$ and 6.4-mM $\mathrm{K}^{+}$is also not significantly different for any experimental combination with or without CBX.

Similar to our studies without CBX, CV slowing with severe hyperkalemia $\left(10-\mathrm{mM} \mathrm{K}^{+}\right)$is observed in hearts perfused with $145-\mathrm{mM} \mathrm{Na}^{+} / 1.25-\mathrm{mM} \mathrm{Ca}^{2+}\left(\mathrm{CV}_{\mathrm{T}}\right.$ and $\mathrm{CV}_{\mathrm{L}}$ slowing), $145-\mathrm{mM} \mathrm{Na}^{+} / 2.00-\mathrm{mM} \mathrm{Ca}^{2+}\left(\mathrm{CV}_{\mathrm{T}}\right.$ slowing only), and $155-\mathrm{mM} \mathrm{Na}^{+} / 1.25-\mathrm{mM} \mathrm{Ca}^{2+}\left(\mathrm{CV}_{\mathrm{T}}\right.$ and $\mathrm{CV}_{\mathrm{L}}$ slowing) solutions (Fig. $5 \mathrm{~b}$ and $\mathrm{c}$ ). Furthermore, CV does not significantly decrease at 10 $\mathrm{mM} \mathrm{K}^{+}$with $155-\mathrm{mM} \mathrm{Na}^{+} / 2.00-\mathrm{mM} \mathrm{Ca}^{2+}$.

\section{Computational model predictions}

To explore potential mechanisms that may explain the experimental results above, the $\mathrm{CV}-\mathrm{K}^{+}$relationship was investigated in silico. The computational model used in Fig. 6 includes GJC and sodium channel localization at the ends of myocytes facing a shared and restricted extracellular cleft with a variable cleft resistance inversely proportional to perinexal width $\left(W_{\mathrm{P}}\right)$. The family of curves in each panel of Fig. 6a-d represents narrow $\left(0.5 \times W_{\mathrm{P}}\right)$, nominal $\left(1 \times W_{\mathrm{P}}\right)$, and wide clefts $(2 \times$ $\left.W_{\mathrm{P}}\right)$ to demonstrate how modulating $\mathrm{EpC}$ alters the $\mathrm{CV}-\mathrm{K}^{+}$ relationship.

The model predicts that progressively narrowing $W_{\mathrm{P}}$ (white to black curves), which enhances EpC, can decrease $\mathrm{CV}$ under conditions of robust GJC and EpC (Fig. 6a). Altering $W_{\mathrm{P}}$ does not dramatically change the positive slope of the linear portion of the $\mathrm{CV}-\mathrm{K}^{+}$curve estimated during supernormal conduction (4.56- through 7-mM K ${ }^{+}$). However, the negative $\mathrm{CV}-\mathrm{K}^{+}$ slope estimated between 9- and $10-\mathrm{mM} \mathrm{K}^{+}$is significantly reduced by narrowing $W_{\mathrm{P}}$. Specifically, the negative slope is $-1.1 \mathrm{~cm} \cdot \mathrm{mM} / \mathrm{sec}$ for the widest clefts $\left(2 \times \mathrm{W}_{\mathrm{P}}\right)$ and $-0.8 \mathrm{~cm}$. $\mathrm{mM} / \mathrm{sec}$ for the narrowest clefts $\left(0.5 \times \mathrm{W}_{\mathrm{P}}\right)$. In short, the model predicts that narrow clefts can attenuate $\mathrm{CV}$ slowing during sodium channel inactivation due to hyperkalemia without notably altering supernormal conduction.

Elevating $\mathrm{Na}^{+}$by $10 \mathrm{mM}$ in this model can modestly increase $\mathrm{CV}$, and narrowing $W_{\mathrm{P}}$ still slows $\mathrm{CV}$. Interestingly, elevating $\mathrm{Na}^{+}$decreases the positive slope 
a
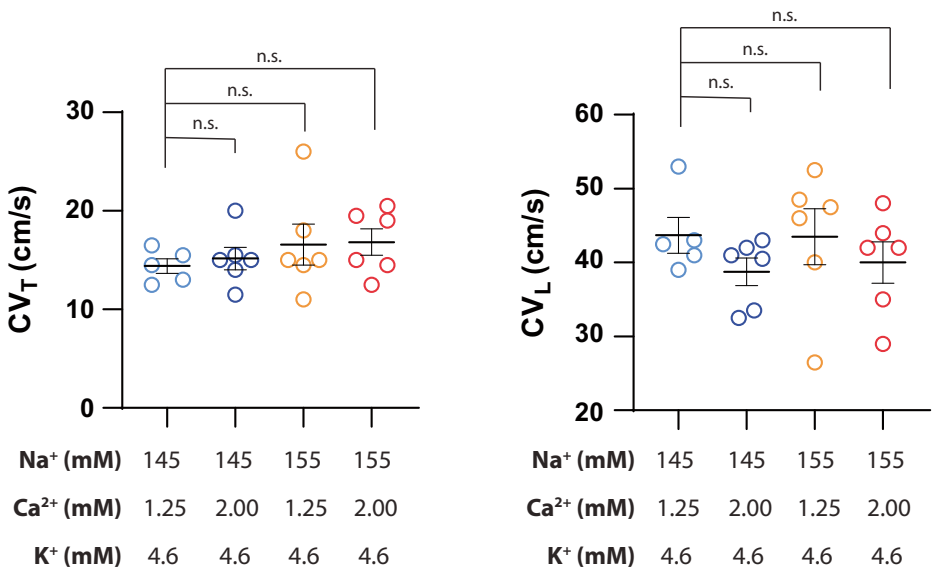

b
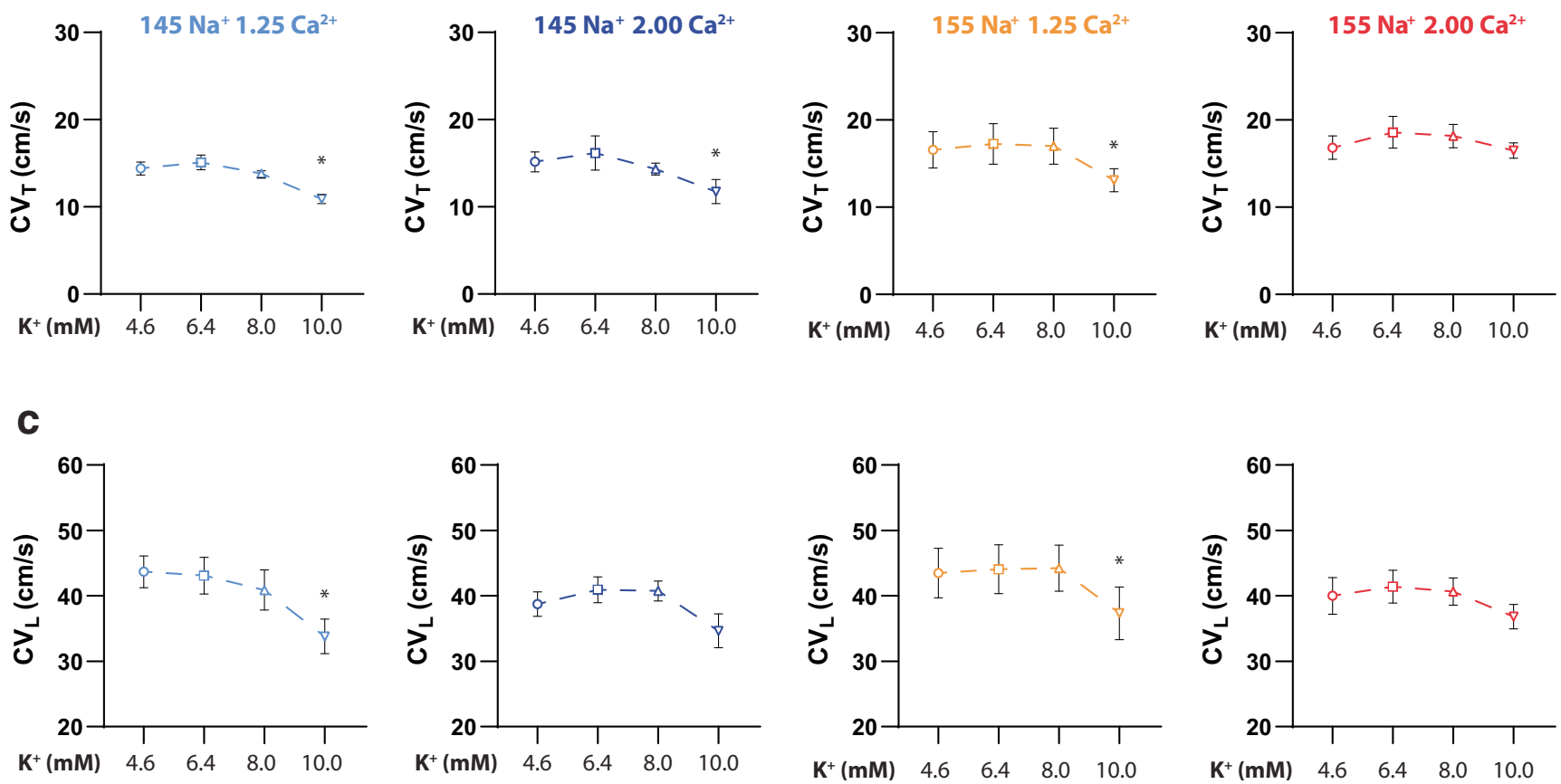

Fig. 5 Following GJ inhibition with $\mathrm{CBX}$, simultaneously increasing $\mathrm{Na}^{+}$and $\mathrm{Ca}^{2+}$ preserves $\mathrm{CV}_{\mathrm{T}}$ and $\mathrm{CV}_{\mathrm{L}}$ at $10.0-\mathrm{mM} \mathrm{K}$. (a) Altering $\mathrm{Na}^{+}, \mathrm{Ca}^{2+}$, or $\mathrm{Na}^{+}$and $\mathrm{Ca}^{2+}$ does not change $\mathrm{CV}_{\mathrm{T}}$ or $\mathrm{CV}_{\mathrm{L}}$ at $4.6-\mathrm{mM}$ $\mathrm{K}^{+}$, (b) Summary of $\mathrm{CV}_{\mathrm{T}}$ as a function of $\mathrm{K}^{+}$in the presence of $\mathrm{CBX}(n=$ $6,7,7,8$ from left to right, respectively), (c) Summary of $\mathrm{CV}_{\mathrm{L}}$ as a

function of $\mathrm{K}^{+}$in the presence of $\mathrm{CBX}(n=6,7,7,8$ from left to right, respectively). Significance determined by ordinary one-way ANOVA with Dunnett's correction for multiple comparisons $(p<0.05$ denoted by *)

of the linear portions of the $\mathrm{CV}-\mathrm{K}^{+}$relationship (Fig. $6 \mathrm{~b})$. In contrast, the negative slope associated with sodium channel inactivation at $10-\mathrm{mM} \mathrm{K}^{+}$is not as dramatically affected by elevating $\mathrm{Na}^{+}$, and the values are similar to the negative slopes under the nominal case in Fig. 6a. Taken together with Fig. 6a, the model predicts that elevating $\mathrm{Na}^{+}$can reduce the sensitivity of $\mathrm{CV}$ to changes in $\mathrm{K}^{+}$during supernormal $\mathrm{CV}$, but the negative slope is still predominantly determined by intercellular cleft width $\left(W_{\mathrm{P}}\right)$ and therefore EpC. Importantly, elevating $\mathrm{Na}^{+}$and reducing $W_{\mathrm{P}}$ attenuate the sensitivity of $\mathrm{CV}$

to $\mathrm{K}^{+}$during supernormal conduction and sodium channel inactivation.

The CV response to reducing GJC by $50 \%(0.5 \times$ GJC) can be found in Fig. 6c. As expected, reducing GJC slows $\mathrm{CV}$, and narrowing $W_{\mathrm{P}}$ still slows $\mathrm{CV}$. The model also suggests that inhibiting GJC does not substantively alter the $\mathrm{CV}-\mathrm{K}^{+}$relationship during supernormal conduction between $4.56-$ and $7-\mathrm{mM} \mathrm{K}^{+}$, but GJC inhibition can increase $\mathrm{CV}$ sensitivity to sodium channel inactivation as evidenced by larger negative slopes in Fig. 6c relative to $6 \mathrm{a}$. Yet, the sensitivity of $\mathrm{CV}$ 

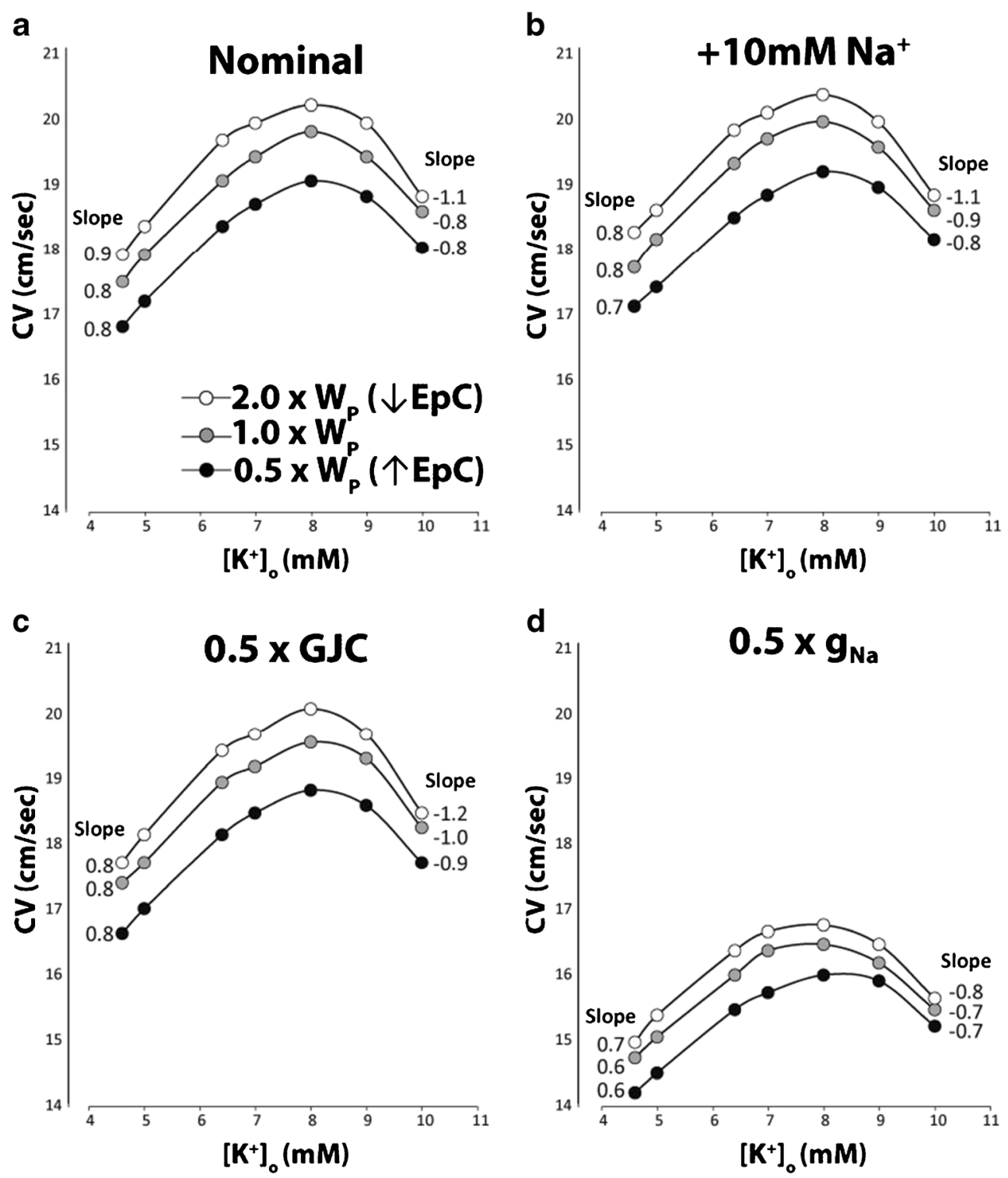

Fig. 6 Computational predictions of modulating perinexal width $\left(W_{\mathrm{P}}\right)$, extracellular sodium concentrations $\left(\mathrm{Na}^{+}\right)$, gap junctional coupling (GJC), and the fast sodium channel conductance (gNa). (a) Increasing $W_{\mathrm{P}}$ to reduce $\mathrm{EpC}$ is associated with increased conduction velocity ( $\mathrm{CV}$, black to white points). The positive slope calculated from a linear fit of $\mathrm{CV}$ over the range of extracellular potassium $\left(\mathrm{K}^{+}\right)$from 4.56 to $7 \mathrm{mM}$ is reduced as $W_{\mathrm{P}}$ decreases. The negative slope associated with sodium channel inactivation over the range of 9- to $10-\mathrm{mM} \mathrm{K}^{+}$decreases to a greater extent with narrow $W_{\mathrm{P}}$, (b) Increasing $\mathrm{Na}^{+}$by $10 \mathrm{mM}(+10-$ $\mathrm{mM} \mathrm{Na}{ }^{+}$) decreases the positive slope of the $\mathrm{CV}-\mathrm{K}^{+}$relationship without

slowing during sodium channel inactivation is still the lowest under conditions of the narrowest cleft widths $\left(0.5 \times \mathrm{W}_{\mathrm{P}}\right)$ and therefore elevated EpC.

When the peak conductance of the fast sodium current is inhibited by $50 \%(0.5 \times \mathrm{gNa}), \mathrm{CV}$ slows dramatically as expected (Fig. 6d). Although narrowing $W_{\mathrm{P}}$ still slows $\mathrm{CV}$, reducing $W_{\mathrm{P}}$ also reduces the positive and negative slopes of the $\mathrm{CV}-\mathrm{K}^{+}$relationship. In summary, the model predicts that enhancing $\mathrm{EpC}$ by

substantively altering the negative slope or CV overall, (c) Reducing GJC by $50 \%(0.5 \times \mathrm{GJC})$ slows $\mathrm{CV}$ for all values of $\mathrm{K}^{+}$without changing the positive $\mathrm{CV}-\mathrm{K}^{+}$slope. However, $0.5 \times \mathrm{GJC}$ is associated with enhanced CV slowing during sodium channel inactivation measured between 9and $10-\mathrm{mM} \mathrm{K}^{+}$relative to the nominal condition in panel b. CV slowing was still the lowest with the narrowest cleft widths $\left(0.5 \times W_{\mathrm{P}}\right)$, (d) Reducing gNa by $50 \%(0.5 \times \mathrm{gNa})$ not only reduces $\mathrm{CV}$ for all $\mathrm{K}^{+}$, but it also reduces both the positive and negative slopes of the $\mathrm{CV}-\mathrm{K}^{+}$relationship, without altering predictions that $W_{\mathrm{P}}$ associated with the slowest $\mathrm{CV}$ attenuates $\mathrm{CV}$-dependent changes on $\mathrm{K}^{+}$

narrowing $W_{\mathrm{P}}$ reduces $\mathrm{CV}$ sensitivity to loss of functional sodium channels induced by increasing sodium channel inactivation $\left(10-\mathrm{mM} \mathrm{K}^{+}\right)$or reduced peak current $(0.5 \times \mathrm{gNa})$. In summary, computational models incorporating both EpC and GJC predict complex CV$\mathrm{K}^{+}$relationships with a consistent finding that narrowing $W_{\mathrm{P}}$ attenuates $\mathrm{CV}$ slowing during sodium channel loss of function induced by sodium channel inactivation or reduced peak sodium current. 


\section{Discussion}

The purpose of this study is to report how elevations in $\mathrm{Na}^{+}$ and/or $\mathrm{Ca}^{2+}$ modify the $\mathrm{CV}-\mathrm{K}^{+}$relationship and determine how these interventions modify the relationship when GJ coupling is reduced. We previously demonstrated that modification of $\mathrm{Na}^{+}$and $\mathrm{Ca}^{2+}$ can alter $\mathrm{CV}$ in a variety of settings including genetically reduced $\mathrm{Cx} 43$ functional expression [13], in hearts exposed to the inflammatory cytokine TNF $\alpha$ [15], simulated metabolic ischemia [16], and global no-flow ischemia $[26,27]$. To our knowledge, this is the first study to demonstrate that elevating $\mathrm{Na}^{+}$and $\mathrm{Ca}^{2+}$ and pharmacologically inhibiting GJC will modulate the $\mathrm{CV}-\mathrm{K}^{+}$relationship nonlinearly.

\section{The relationship between conduction and $\mathrm{K}^{+}$}

It is well established that the $\mathrm{CV}-\mathrm{K}^{+}$relationship is biphasic and can be modulated by other ions such as hydrogen $(\mathrm{pH})[32$, $52,35]$. In the range of hypo-, normo-, and mild-hyperkalemia, the relationship between $\mathrm{CV}$ and $\mathrm{K}^{+}$is positively correlated, and supernormal conduction is the term coined to describe the observed increase in cardiac $\mathrm{CV}$ as $\mathrm{K}^{+}$rises above normal plasma concentrations. Mechanistically, elevating extracellular $\mathrm{K}^{+}$depolarizes the plasma membrane and reduces the difference between the RMP and the voltage gated sodium channel activation threshold $[30,44]$. As a result, the net cellular charge accumulation required to reach the sodium channel activation threshold is reduced, sodium channel activation occurs earlier, and CV increases. It is equally well established that voltage gated sodium channel inactivation is related to membrane potential, as postulated most famously by Hodgkin and Huxley in 1952 [25, 24]. Therefore, as the RMP continues to rise consequent of increased extracellular $\mathrm{K}^{+}$, more sodium channels accumulate in the inactive state and the net sodium channel availability will decrease.

\section{Supernormal conduction}

Our data demonstrate that $\mathrm{CV}$ increases when $\mathrm{K}^{+}$is elevated between 4.6 and $6.4 \mathrm{mM}$ with presumably normal GJC, and this is consistent with previous studies and mathematical models $[32,61]$. Importantly, our data also suggest that supernormal conduction is relatively insensitive to the investigated changes of $\mathrm{Na}^{+}$and $\mathrm{Ca}^{2+}$ used in this study. Of note, the relatively nonspecific GJC inhibitor CBX $(30 \mu \mathrm{M})$ decreases $\mathrm{CV}$ for all $\mathrm{K}^{+}$concentrations and abolishes the significant increase in supernormal $\mathrm{CV}$ when $\mathrm{K}^{+}$is elevated from 4.6 to $6.4 \mathrm{mM}$. This could be due to an effect size below our resolution to detect as a result of increased CV variability introduced by the compound, or CBX actually decreases supernormal CV sensitivity.

Adding further complexity, the data presented herein are in apparent contrast with one of our previous studies in which
$\mathrm{CV}$ decreased consequent of a modest elevation in $\mathrm{K}^{+}$(from 4.1 to $6.1 \mathrm{mM}$ ) in conjunction with $155-\mathrm{mM} \mathrm{Na}^{+}$and $1.8-\mathrm{mM}$ $\mathrm{Ca}^{2+}$ in a murine model [18]. This may be due to the fact that there are underlying differences in normal plasma electrolyte concentrations between murine and guinea pig models [62]. The possibility that the $\mathrm{CV}-\mathrm{K}^{+}$relationship may be species dependent will require further investigation and may provide further insight into the complex regulation of cardiac $\mathrm{CV}$.

\section{Conduction slowing due to sodium channel inactivation}

As mentioned previously, $\mathrm{K}^{+}$-induced RMP depolarization will eventually impinge on steady-state sodium channel inactivation and decrease total sodium channel availability [61, 74]. In our study, elevating $\mathrm{K}^{+}$from 4.6 to $10 \mathrm{mM}$ slows $\mathrm{CV}$ for every $\mathrm{Na}^{+}$and $\mathrm{Ca}^{2+}$ combination except one. Interestingly, and regardless of the presence of CBX, 155$\mathrm{mM} \mathrm{Na}^{+}$and $2.00-\mathrm{mM} \mathrm{Ca}^{2+}$ is the only ionic combination in this study that is not associated with CV slowing at 10$\mathrm{mM} \mathrm{K} \mathrm{K}^{+}$. It is important to note that this lack of change in $\mathrm{CV}$ from $4.6 \mathrm{mM} \mathrm{K}^{+}$may be due to experimental undersampling of the continuous $\mathrm{CV}-\mathrm{K}^{+}$relationship. There are at least four possible explanations for this finding. First, this could be a type II statistical error. However, the finding that $\mathrm{CV}$ does not change between $4.6-$ and $10-\mathrm{mM} \mathrm{K}^{+}$only with the $155-\mathrm{mM} \mathrm{Na}^{+} / 2.00-\mathrm{mM} \mathrm{Ca}^{2+}$ perfusate is consistent with and without CBX. This increases our confidence that the resultis not a statistical error. Second, the ionic combination could minimize $\mathrm{CV}$ changes across the range of $\mathrm{K}^{+}$values studied. Third, the mechanisms governing super-normal conduction and those governing conduction slowing due to sodium channel inactivation could be related but produce fundamentally different $\mathrm{CV}-\mathrm{K}^{+}$slopes. Lastly, the ionic combination could attenuate conduction slowing by right-shifting the $\mathrm{K}^{+}$range that slows $\mathrm{CV}$.

\section{Proposed mechanisms: cellular determinants of conduction}

Divalent cations, such as $\mathrm{Ca}^{2+}$, inhibit $I_{\mathrm{K} 1}$ [4]. Inhibition of $I_{\mathrm{K} 1}$ should depolarize the RMP and therefore left shift the CV-K ${ }^{+}$ curve. If this were responsible for our experimental results, one would expect that $2.00-\mathrm{mM} \mathrm{Ca}^{2+}$ should significantly slow conduction more at $10-\mathrm{mM} \mathrm{K}^{+}$relative to $1.25-\mathrm{mM}$ $\mathrm{Ca}^{2+}$. We did not observe this. Specifically, CV slows similarly for $1.25-$ and $2.00-\mathrm{mM} \mathrm{Ca}^{2+}$ groups at $145-\mathrm{mM} \mathrm{Na}^{+}$. Furthermore, elevating $\mathrm{Ca}^{2+}$ actually attenuates conduction slowing at $155-\mathrm{mM} \mathrm{Na}^{+}$.

We also appreciate that $\mathrm{Ca}^{2+}$ is a potent secondary messenger and essential for enzymes including $\mathrm{Ca}^{2+} /$ calmodulin-dependent protein kinase II (CaMKII) [65, 28, 72]. With regard to cardiac conduction, some have reported that increasing 
CaMKII activity can negatively shift sodium channel steadystate inactivation, thereby reducing peak $I_{\mathrm{Na}}[1,3,21]$. Elevating $\mathrm{Ca}^{2+}$ and even decreasing $\mathrm{Na}^{+}$should be associated with enhanced intracellular $\mathrm{Ca}^{2+}[7,34]$, increased CaMKII activation, reduced $I_{\mathrm{Na}}$, and therefore conduction slowing. Once again, our results are not entirely consistent with the hypothesized effects of CaMKII activation. For example, one would expect to measure the greatest conduction slowing with solutions containing elevated $\mathrm{Ca}^{2+}$ and/or decreased $\mathrm{Na}^{+}$. Even though conduction slowing is observed with $145-\mathrm{mM}$ $\mathrm{Na}^{+} / 1.25-\mathrm{mM} \mathrm{Ca}^{2+}$, conduction slows similarly to $145-\mathrm{mM}$ $\mathrm{Na}^{+} / 2.00-\mathrm{mM} \mathrm{Ca}^{2+}$ and $155-\mathrm{mM} \mathrm{Na}^{+} / 1.25-\mathrm{mM} \mathrm{Ca}^{2+}$. Only $155-\mathrm{mM} \mathrm{Na}^{+} / 2.00-\mathrm{mM} \mathrm{Ca}^{2+}$ is not associated with significant conduction slowing at $10-\mathrm{mM} \mathrm{K}^{+}$, and this should be slower than conduction measured with $145-\mathrm{mM} \mathrm{Na}^{+} / 2.00-\mathrm{mM} \mathrm{Ca}^{2+}$, because reduced extracellular $\mathrm{Na}^{+}$should also increase intracellular $\mathrm{Ca}^{2+}$ [34]. Importantly, the data do not exclude the importance of CaMKII post-translational modification of Nav1.5.

\section{Proposed mechanisms: intercellular coupling determinants of conduction}

To our knowledge, this is the first study to evaluate the CV-K relationship consequent to GJ uncoupling. While the GJC inhibitor CBX has documented non-GJ-related off-target effects, it is a well-established model of pharmacologically induced GJC inhibition in cardiac preparations [20, 37, 10]. Regardless of the concentration of $\mathrm{Na}^{+}$or $\mathrm{Ca}^{2+}, \mathrm{CBX}$ slowed conduction relative to preparations without CBX. Similar to preparations without $\mathrm{CBX}$, the addition of $\mathrm{CBX}$ did not produce significant differences in the $\mathrm{CV}-\mathrm{K}^{+}$relationship with different perfusate combinations. Interestingly, the lack of observable conduction changes consequent of perturbations to $\mathrm{Na}^{+}$or $\mathrm{Ca}^{2+}$ in this study at $4.6-\mathrm{mM} \mathrm{K}^{+}$is in contrast to individual ion associated changes in conduction observed in the aforementioned murine model of genetically reduced Cx43 [18]. However, the combination of enhanced $\mathrm{Na}^{+}$and $\mathrm{Ca}^{2+}$ does attenuate $\mathrm{CBX}$-induced $\mathrm{CV}$ slowing in guinea pig consistent with findings in mice with genetically downregulated $\mathrm{Cx} 43$.

The fact that the findings with pharmacologically induced GJC inhibition in guinea pig does not correlate one to one with genetically reduced functional GJC in mouse warrants additional investigation. Factors to consider include the off-target effects of CBX, the unknown degree of GJC inhibition elicited by $\mathrm{CBX}$, and the fact that genetically manipulated animal models of protein functional expression are associated with off-target protein remodeling [64, 55, 29, 49]. Still, the conclusion that ionic modulation of cardiac conduction can be GJ-dependent is consistent across species with different interventions to induce GJ uncoupling. Understanding species differences, particularly as mice have different plasma electrolyte concentrations from human as noted above, is important since individual variations in extracellular ion homeostasis may underlie subtle variations in phenotype [39].

The computational model is important to inform our understanding of how GJC and enhanced EpC (by reduced $W_{\mathrm{P}}$ ) modulate conduction under the many conditions experimentally explored in this study. We first note that the model is tuned to study $\mathrm{CV}$ in the range of significant EpC selfattenuation in the presence of robust GJC. Briefly, selfattenuation is proposed to work in two ways. First, activation of voltage gated sodium channels facing narrow extracellular nanodomains will decrease the junctional extracellular potential $\left(\Phi_{\mathrm{J}}\right)$ by charge withdrawal from the nanodomain and raise the transmembrane potential $\left(V_{\mathrm{m}}\right)$ of apposing membranes, where $\left[V_{\mathrm{m}}=\left(\Phi_{\mathrm{i}}-\Phi_{\mathrm{J}}\right)\right]$ and $\Phi_{\mathrm{i}}$ represents the intracellular potential. Secondly, sodium withdrawal from the nanodomain also decreases extracellular $\mathrm{Na}^{+}$and, by the Nernst equation, will decrease the sodium equilibrium potential $\left(E_{\mathrm{Na}}\right)$ and therefore the driving force for ion entry into the cell [Driving Force $\left.=\left(V_{\mathrm{m}}-E_{\mathrm{Na}}\right)\right]$. As both the extracellular potential $\left(\Phi_{\mathrm{J}}\right)$ and $E_{\mathrm{Na}}$ rapidly decrease, the driving force for $\mathrm{Na}^{+}$through sodium channels approaches zero more rapidly and hence the term "self-attenuation." Under conditions of robust GJC, the intracellular potential $\left(\Phi_{\mathrm{i}}\right)$ also rises more rapidly due to current through GJs and causes $V_{\mathrm{m}}$ to increase rapidly. Thus, with both elevated GJC and EpC, all three parameters that define the driving force $\left[\Phi_{\mathrm{i}}-\Phi_{\mathrm{J}}-E_{\mathrm{Na}}\right]$ for sodium channels change concurrently and reduce peak $I_{\mathrm{Na}}$ at the intercalated disc, while simultaneously increasing the rate of voltage gated sodium channel opening as a result of rapid $V_{\mathrm{m}}$ changes. In short, the relationship between $\mathrm{EpC}$, GJC, and $\mathrm{CV}$ is complex because both mechanisms are important for determining the rate of action potential propagation, while simultaneously limiting peak $I_{\mathrm{Na}}$.

As a result of these complementary mechanisms, the relationship between $\mathrm{CV}$ and the cleft width between neighboring myocytes is biphasic [40, 41]. Models predict that CV will increase when cleft separation between myocytes increases but only when clefts are relatively narrow. In this range, widening clefts reduces self-attenuation and increases CV. As clefts continue to widen the role of EpC action potential transmission is reduced, and CV becomes more dependent on GJC. The slower intracellular charge transfer through GJC still maintains robust cardiac conduction, but $\mathrm{CV}$ decreases as $\mathrm{EpC}$ is removed from the process of intracellular communication. This is important, because models of GJC and EpC should consider the assumptions of EpC and GJC when extrapolating to potential mechanisms. Case in point, in Supplemental Figure 3, GJC is reduced by $98 \%$ to increase $\mathrm{CV}$ dependence on EpC. Under these conditions, narrowing cleft width now increases CV in contrast to Fig. 6a where GJC is robust. Under conditions of almost no GJC, narrowing cleft width increases the sensitivity of the $\mathrm{CV}-\mathrm{K}^{+}$relationship to 
$W_{\mathrm{P}}$ in a manner opposite to what is found in Fig. 6a. Interestingly, the model in Fig. 6 and Supplemental Figure 3 suggests that when EpC is present, the cleft widths associated with slowest $\mathrm{CV}$ attenuate supernormal $\mathrm{CV}$ and $\mathrm{CV}$ slowing consequent to sodium channel loss of function.

Furthermore, the model presented in Fig. 6 replicates key experimental conditions and outcomes, suggesting that elevating $\mathrm{Na}^{+}$and reducing $W_{\mathrm{P}}$ can attenuate the positive and negative slopes of the $\mathrm{CV}-\mathrm{K}^{+}$relationship, but the model is not precisely tuned to replicate the experimental finding that 10$\mathrm{mM} \mathrm{K}^{+}$slows $\mathrm{CV}$ below values obtained at $4.6-\mathrm{mM} \mathrm{K}^{+}$in experiments. The model also predicts that altering $W_{\mathrm{P}}$ can attenuate the positive $\mathrm{CV}-\mathrm{K}^{+}$slope during supernormal $\mathrm{CV}$, but this was not observed experimentally. However, the model may have explored changes in $W_{\mathrm{P}}$ greater than those experimentally induced, $\mathrm{CV}$ changes could be below our resolution to experimentally detect, or our model assumptions require further tuning in a complex and emergent multiparametric space. This assertion is not just conjecture. Computational models have long predicted that altering the distribution of sodium channels in the lateral membrane and cleft to include electric field and EpC dramatically alters myocardial electrophysiology to explain contentious issues including the relationship between CV and GJC [38, 48, 40, 68, 70, 18, 73, 22, 16, 27], $\mathrm{CV}$ and sodium channel loss of function [66, 70, 67], and APD and sodium channel gain of function [19, 50, 51]. Importantly, the experimental data and computational models suggest that both EpC and GJC are sufficiently robust in the experimental setup used in this study, such that small changes in $W_{\mathrm{P}}$ may either modestly increase $\mathrm{CV}$ or not change it significantly as reported above. The finding that $\mathrm{CV}$ slows to a similar degree at $10-\mathrm{mM} \mathrm{K}^{+}$with and without GJC inhibition is also worth noting, as the model suggests $\mathrm{CV}$ slowing should be enhanced with GJC, but we do not know (1) if the expected CV change was below our resolution to detect, (2) the degree to which 30- $\mu \mathrm{M}$ CBX inhibits GJC, or (3) whether previously reported $W_{\mathrm{P}}$ narrowing with $\mathrm{CBX}$ [11] reduces the negative slope of the $\mathrm{CV}-\mathrm{K}^{+}$relationship during sodium channel inactivation. Regardless, the experimental data and computational models are complementary. The solution associated with the strongest $\mathrm{EpC}$ $\left(155-\mathrm{mM} \mathrm{Na}^{+} / 2.00-\mathrm{mM} \mathrm{Ca}^{2+}\right)$ is not associated with conduction slowing at $10-\mathrm{mM} \mathrm{K}^{+}$. In other words, this study supports a hypothesis that enhanced EpC attenuates CV slowing secondary to functional loss of voltage gated sodium channels.

\section{Asystole in the presence of severe hyperkalemia}

In the presence of $145-\mathrm{mM} \mathrm{Na}^{+}$, with normal GJC, the majority of hearts became asystolic during $10-\mathrm{mM} \mathrm{K}^{+}$perfusion. This is likely due to a reduced sodium channel availability consequent to extracellular $\mathrm{K}^{+}$-induced membrane depolarization. In contrast, a significantly higher number of hearts remained in intrinsic rhythm during $10-\mathrm{mM} \mathrm{K}^{+}$perfusion in the presence of $155-\mathrm{mM} \mathrm{Na}^{+}$. The mechanism by which this occurs is unknown, since asystole may be caused by altered automaticity, a lack of excitability, or a failure for the excitable signal to propagate into the myocardium.

Inhibiting GJs with CBX significantly decreases the incidence of asystole in hearts perfused with $145-\mathrm{mM} \mathrm{Na}^{+}$and 10 $\mathrm{mM} \mathrm{K}^{+}$. This is an unexpected finding as precedent literature provides evidence for a necessary role of robust GJC in coordinated nodal tissue excitability $[9,46,47]$. An important caveat of our experimental condition however is that the atria, and thereby the sino-atrial node, are removed from the preparation. Previous literature also provides that limiting current sink, as would happen in the context of uncoupled GJs, lowers the source charge required for excitation [60]. Per this line of thought, uncoupling GJs may facilitate entrained or propagated autorhythmic coordination in the context of otherwise lowered cellular excitability (severe hyperkalemia). The precise mechanism of how GJ uncoupling maintains intrinsic rhythm in the context of severe hyperkalemia warrants further investigation.

\section{Perspective on isolated heart experiments}

These results have important implications for preclinical cardiovascular research, particularly in the context of isolated organ experiments, when considering how laboratory perfusates are chosen. The level of variation in perfusate composition between laboratories is significant. Common differences in perfusate compositions include modifications to ubiquitous electrolytes such as $\mathrm{Na}^{+}, \mathrm{Ca}^{2+}, \mathrm{K}^{+}, \mathrm{Mg}^{2+}$, and $\mathrm{Cl}^{-}$, buffering agents, electromechanical uncouplers, $\mathrm{pH}$, and addition of any proteins or fatty acids. The results of this manuscript, along with many of our previous studies, highlight the impact that modest changes in electrolyte composition can have on cardiac function in the Langendorff-perfused ex vivo heart and may help to explain some experimental discrepancies found in the literature.

\section{Clinical implications}

Clinically, hyperkalemia is associated with diseases such as ischemia, renal failure, and HIV; medications such as ACE inhibitors, penicillin, and heparin; and acute injury such as crush injury and burns $[53,74]$. Severe hyperkalemia, if left untreated, can result in sudden cardiac death. One mechanism by which hyperkalemia can lead to sudden cardiac death is by elevating the RMP and effectively reducing sodium channel availability.

While our present study investigates the consequence of variations in $\mathrm{Na}^{+}$and $\mathrm{Ca}^{2+}$ in the context of hyperkalemia, the results have broader implications for diseases associated with decreased sodium channel functional expression or diseases aggravated by increased extracellular $\mathrm{K}^{+}$. For example, hyperkalemia-induced steady-state inactivation may mimic the loss of $I_{\mathrm{Na}}$ associated with multiple diseases such as some 
congenital forms of Brugada syndrome and Duchenne muscular dystrophy $[2,54,36]$. In fact, the computational modeling in Fig. 6 suggests that narrowing $W_{\mathrm{P}}$ attenuates $\mathrm{CV}$ slowing during sodium channel loss of function either due to sodium channel inactivation $\left(10-\mathrm{mM} \mathrm{K}^{+}\right)$or reduced channel unitary conductance $(0.5 \times \mathrm{gNa})$. The results are timely as clinical case reports suggest that both Brugada syndrome and Brugada phenocopies may be either unmasked or induced, respectively, by hyperkalemia [59]. The finding that conduction slowing is greatest secondary to hyperkalemic sodium channel inactivation under conditions of reduced $\mathrm{EpC}$ is consistent with similar findings where pharmacologic sodium channel inhibition is exacerbated by reduced EpC [71, 67]. This study, in the context of previous findings, supports a hypothesis that Brugada syndrome is modulated by EpC. In fact, a very recent and independent computational study supports this hypothesis by demonstrating how EpC can modulate conduction and phase 2 reentry in Brugada syndrome [67]. Thus, our study supports a growing body of evidence that EpC may be an effective target to treat cardiac diseases associated with a reduction in myocardial sodium current density. Though, further studies are needed to determine whether such ionic changes may indeed modulate conduction deficits in the context of diseases with reduced functional sodium channel expression in a clinical setting.

\section{Conclusion}

In the present study, we provide evidence that altering $\mathrm{Na}^{+}$and $\mathrm{Ca}^{2+}$ will modify the well-established $\mathrm{CV}-\mathrm{K}^{+}$relationship. These results again demonstrate the importance of perfusate composition in studying cardiac function. At the bench, the respective changes in electrolyte concentrations may seem small but can have profound impacts on cardiac function and may even explain disparate outcomes within the field $[13,16,34]$.

Considering the frequency of presentation and pernicious nature of clinical hyperkalemia, it is important that we further understand the influence of electrolytic imbalances on the CV$\mathrm{K}^{+}$relationship. While our results do not offer an immediate therapeutic option, they do suggest that the combined elevation of $\mathrm{Na}^{+}$and $\mathrm{Ca}^{2+}$ could preserve $\mathrm{CV}$ in the context of severe hyperkalemia and/or sodium channel loss of function and may have the potential to reduce arrhythmogenic conduction slowing and block.

Supplementary Information The online version contains supplementary material available at https://doi.org/10.1007/s00424-021-02537-y.

Acknowledgments This study was supported by National Institutes of Health F31-HL147438 awarded to DRK, National Institutes of Health R01-HL141855, R01-HL138003, and R01-HL102298 awarded to SP, and National Institutes of Health UL1TR003015 awarded to ALF.
Data availability The datasets generated and/or analyzed during the current study are available from the corresponding author on reasonable request.

Open Access This article is licensed under a Creative Commons Attribution 4.0 International License, which permits use, sharing, adaptation, distribution and reproduction in any medium or format, as long as you give appropriate credit to the original author(s) and the source, provide a link to the Creative Commons licence, and indicate if changes were made. The images or other third party material in this article are included in the article's Creative Commons licence, unless indicated otherwise in a credit line to the material. If material is not included in the article's Creative Commons licence and your intended use is not permitted by statutory regulation or exceeds the permitted use, you will need to obtain permission directly from the copyright holder. To view a copy of this licence, visit http://creativecommons.org/licenses/by/4.0/.

\section{References}

1. Aiba T, Hesketh GG, Liu T, Carlisle R, Villa-Abrille MC, O'Rourke B, Akar FG, Tomaselli GF (2010) Na+ channel regulation by $\mathrm{Ca} 2+/$ calmodulin and $\mathrm{Ca} 2+/$ calmodulin-dependent protein kinase II in guinea-pig ventricular myocytes. Cardiovasc Res. 85(3):454-463. https://doi.org/10.1093/cvr/cvp324

2. Antzelevitch C (2006) Brugada syndrome. PACE - Pacing Clin Electrophysiol. 29(10):1130-1159. https://doi.org/10.1111/j.15408159.2006.00507.x

3. Ashpole NM, Herren AW, Ginsburg KS, Brogan JD, Johnson DE, Cummins TR, Bers DM, Hudmon A (2012) Ca 2+/calmodulin-dependent protein kinase II (CaMKII) regulates cardiac sodium channel $\mathrm{Na} \mathrm{V}$ 1.5 gating by multiple phosphorylation sites. J Biol Chem. 287(24): 19856-19869. https://doi.org/10.1074/jbc.M111.322537

4. Bartos DC, Grandi E, Ripplinger CM (2015) Ion channels in the heart. Compr Physiol. 5(3):1423-1464. https://doi.org/10.1002/ cphy.c140069

5. Bates D, Mächler M, Bolker B, Walker S (2015) Fitting linear mixed-effects models using lme4. J Stat Softw 67(1). https://doi. org/10.18637/jss.v067.i01

6. Bayly PV, KenKnight BH, Rogers JM, Hillsley RE, Ideker RE, Smith WM (1998) Estimation of conduction velocity vector fields from epicardial mapping data. IEEE Trans Biomed Eng. 45(5): 563-571. https://doi.org/10.1109/10.668746

7. Bridge JHB, Smolley JR, Spitzer KW (1990) The relationship between charge movements associated with $\mathrm{ICa}$ and $\mathrm{INa}-\mathrm{Ca}$ in cardiac myocytes. Science (80- ) 248(4953):376-378. https://doi.org/10. $1126 /$ science. 2158147

8. Buchanan JW, Saito T, Gettes LS (1985) The effects of antiarrhythmic drugs, stimulation frequency and potassium-induced resting membrane potential changes on conduction velocity and $\mathrm{dV} /$ $\mathrm{dt}(\max )$ in guinea pig myocardium. Circ Res. 56(5):696-703. https://doi.org/10.1161/01.RES.56.5.696

9. Delmar M, Jalife J, Michaels DC (1986) Effects of changes in excitability and intercellular coupling on synchronization in the rabbit sino-atrial node. J Physiol. 370:127-150. https://doi.org/10. 1113/jphysiol.1986.sp015926

10. Dhillon PS, Gray R, Kojodjojo P, Jabr R, Chowdhury R, Fry CH, Peters NS (2013) Relationship between gap-junctional conductance and conduction velocity in mammalian myocardium. Circ Arrhythmia Electrophysiol. 6(6):1208-1214. https://doi.org/10. 1161/CIRCEP.113.000848

11. Entz M, George SA, Zeitz MJ, Raisch T, Smyth JW, Poelzing S (2016) Heart rate and extracellular sodium and potassium modulation of gap 
junction mediated conduction in guinea pigs. Front Physiol 7(FEB):110. https://doi.org/10.3389/fphys.2016.00016

12. Entz MW, King DR, Poelzing S (2017) Design and validation of a tissue bath 3D printed with PLA for optically mapping suspended whole heart preparations. Am J Physiol - Hear Circ Physiol. Published online September 22 http://ajpheart.physiology.org/ content/early/2017/09/20/ajpheart.00150.2017.abstract

13. George SA, Poelzing S (2016) Cardiac conduction in isolated hearts of genetically modified mice-connexin 43 and salts. Prog Biophys Mol Biol. 120(1-3):189-198. https://doi.org/10. 1016/j.pbiomolbio.2015.11.004

14. George SA, Bonakdar M, Zeitz M, Davalos RV, Smyth JW, Poelzing S (2016) Extracellular sodium dependence of the conduction velocity-calcium relationship: evidence of ephaptic self-attenuation. Am J Physiol Heart Circ Physiol. 310(9):H1129-H1139. https://doi.org/10.1152/ajpheart.00857.2015

15. George SA, Calhoun PJ, Gourdie RG, Smyth JW, Poelzing S (2017) TNF $\alpha$ modulates cardiac conduction by altering electrical coupling between myocytes. Front Physiol. 8:334. https://doi.org/ 10.3389/fphys.2017.00334

16. George SA, Hoeker G, Calhoun PJ, Entz M II, Raisch TB, King DR, Khan M, Baker C, Gourdie RG, Smyth JW, Nielsen MS, Poelzing S (2019) Modulating cardiac conduction during metabolic ischemia with perfusate sodium and calcium in guinea pig hearts. Am J Physiol Heart Circ Physiol. 316(4):H849-H861. https://doi. org/10.1152/ajpheart.00083.2018

17. George SA, Poelzing S (2016) Cardiac conduction in isolated hearts of genetically modified mice-Connexin 43 and salts. Prog Biophys Mol Biol. 120(1-3):189-198. https://doi.org/10.1016/j.pbiomolbio. 2015.11.004

18. George SA, Sciuto KJ, Lin J, Salama ME, Keener JP, Gourdie RG, Poelzing S (2015) Extracellular sodium and potassium levels modulate cardiac conduction in mice heterozygous null for the Connexin43 gene. Pflugers Arch. 467(11):2287-2297. https://doi. org/10.1007/s00424-015-1698-0

19. Greer-Short A, George SA, Poelzing S, Weinberg SH (2017) Revealing the concealed nature of long-QT type 3 syndrome. Circ Arrhythm Electrophysiol. 10(2):e004400. https://doi.org/10.1161/ CIRCEP.116.004400

20. De Groot JR, Veenstra T, Verkerk AO et al (2003) Conduction slowing by the gap junctional uncoupler carbenoxolone. Cardiovasc Res. 60(2):288-297. https://doi.org/10.1016/j. cardiores.2003.07.004

21. Hegyi B, Bers DM, Bossuyt J (2019) CaMKII signaling in heart diseases: emerging role in diabetic cardiomyopathy. J Mol Cell Cardiol. 127:246-259. https://doi.org/10.1016/j.yjmcc.2019.01.001

22. Hichri E, Abriel H, Kucera JP (2018) Distribution of cardiac sodium channels in clusters potentiates ephaptic interactions in the intercalated disc. J Physiol. 596(4):563-589. https://doi.org/10.1113/JP275351

23. Hoagland DT, Santos W, Poelzing S, Gourdie RG (2019) The role of the gap junction perinexus in cardiac conduction: potential as a novel anti-arrhythmic drug target. Prog Biophys Mol Biol. 144:4150. https://doi.org/10.1016/j.pbiomolbio.2018.08.003

24. Hodgkin AL, HUXLEY AF (1952) A quantitative description of membrane current and its application to conduction and excitation in nerve. J Physiol. 117(4):500-544. https://doi.org/10.1113/ jphysiol.1952.sp004764

25. HODGKIN AL, HUXLEY AF (1952) The dual effect of membrane potential on sodium conductance in the giant axon of Loligo. J Physiol. 116(4):497-506. https://doi.org/10.1113/jphysiol.1952.sp004719

26. Hoeker GS, James CC, Barrett SH, Smyth JW, Poelzing S (2018) Combined effects of gap junctional and ephaptic coupling therapies on conduction and arrhythmogenesis during ischemia/reperfusion. Biophys J. 114(3):623a. https://doi.org/10.1016/j.bpj.2017.11.3368

27. Hoeker GS, James CC, Tegge AN, Gourdie RG, Smyth JW, Poelzing S Attenuating loss of cardiac conduction during no-flow ischemia through changes in perfusate sodium and calcium. Am J Physiol Circ Physiol. Published online July 17, 2020: ajpheart.00112.2020. https://doi.org/10.1152/ajpheart.00112.2020

28. Hund TJ, Mohler PJ (2015) Role of CaMKII in cardiac arrhythmias. Trends Cardiovasc Med. 25(5):392-397. https://doi.org/10.1016/j. tcm.2014.12.001

29. Jansen JA, Noorman M, Musa H, Stein M, de Jong S, van der Nagel R, Hund TJ, Mohler PJ, Vos MA, van Veen TA, de Bakker JM, Delmar M, van Rijen HV (2012) Reduced heterogeneous expression of $\mathrm{Cx} 43$ results in decreased Nav1.5 expression and reduced sodium current that accounts for arrhythmia vulnerability in conditional Cx43 knockout mice. Hear Rhythm. 9(4):600-607. https:// doi.org/10.1016/j.hrthm.2011.11.025

30. January CT, Fozzard HA (1984) The effects of membrane potential, extracellular potassium, and tetrodotoxin on the intracellular sodium ion activity of sheep cardiac muscle. Circ Res. 54(6):652-665. https://doi.org/10.1161/01.RES.54.6.652

31. Jeevaratnam K, Chadda KR, Huang CLH, Camm AJ (2018) Cardiac potassium channels: physiological insights for targeted therapy. J Cardiovasc Pharmacol Ther. 23(2):119-129. https://doi. org/10.1177/1074248417729880

32. Kagiyama Y, Hill JL, Gettes LS (1982) Interaction of acidosis and increased extracellular potassium on action potential characteristics and conduction in guinea pig ventricular muscle. Circ Res. 51(5): 614-623. https://doi.org/10.1161/01.RES.51.5.614

33. Kanno T, Matsuda K (1966) The effects of external sodium and potassium concentration on the membrane potential of atrioventricular fibers of the toad. J Gen Physiol. 50(2):243-253. https://doi. org/10.1085/jgp.50.2.243

34. King DR, Padget RL, Perry J, Hoeker G, Smyth JW, Brown DA, Poelzing S (2020) Elevated perfusate $[\mathrm{Na}+]$ increases contractile dysfunction during ischemia and reperfusion. Sci Rep. 10(1): 17289. https://doi.org/10.1038/s41598-020-74069-x

35. KLÉBER AG, RUDY Y (2004) Basic mechanisms of cardiac impulse propagation and associated arrhythmias. Physiol Rev. 84(2): 431-488. https://doi.org/10.1152/physrev.00025.2003

36. Koenig X, Ebner J, Hilber K (2018) Voltage-dependent sarcolemmal ion channel abnormalities in the dystrophin-deficient heart. Int J Mol Sci. 19(11). https://doi.org/10.3390/ijms19113296

37. Kojodjojo P, Kanagaratnam P, Segal OR, Hussain W, Peters NS (2006) The effects of carbenoxolone on human myocardial conduction. J Am Coll Cardiol. 48(6):1242-1249. https://doi.org/10.1016/ j.jacc.2006.04.093

38. Kucera JP, Rohr S, Rudy Y (2002) Localization of sodium channels in intercalated disks modulates cardiac conduction. Circ Res. 91(12):1176-1182. https://doi.org/10.1161/01.RES.0000046237. $54156.0 \mathrm{~A}$

39. Kurtz D, Travlos G (2017) No Title. In: The Clinical Chemistry of Laboratory Animals. Third. Taylor \& Francis https://www. taylorfrancis.com/books/9781420091144

40. Lin J, Keener JP (2010) Modeling electrical activity of myocardial cells incorporating the effects of ephaptic coupling. Proc Natl Acad Sci. 107(49):20935-20940. https://doi.org/10.1073/pnas.1010154107

41. Lin J, Keener JP (2013) Ephaptic coupling in cardiac myocytes. IEEE Trans Biomed Eng. 60(2):576-582. https://doi.org/10.1109/ TBME.2012.2226720

42. Lin J, Keener JP (2014) Microdomain effects on transverse cardiac propagation. Biophys J. 106(4):925-931. https://doi.org/10.1016/j. bpj.2013.11.1117

43. Luo CH, Rudy Y (1991) A model of the ventricular cardiac action potential. Depolarization, repolarization, and their interaction. Circ Res. 68(6):1501-1526. https://doi.org/10.1161/01.res.68.6.1501

44. Mangold KE, Brumback BD, Angsutararux P, Voelker TL, Zhu W, Kang PW, Moreno JD, Silva JR (2017) Mechanisms and models of cardiac sodium channel inactivation. Channels. 11(6):517-533. https://doi.org/10.1080/19336950.2017.1369637 
45. Mezache L, Struckman HL, Greer-Short A, Baine S, Györke S, Radwański PB, Hund TJ, Veeraraghavan R (2020) Vascular endothelial growth factor promotes atrial arrhythmias by inducing acute intercalated disk remodeling. Sci Rep. 10(1):20463. https://doi.org/ 10.1038/s41598-020-77562-5

46. Michaels DC, Matyas EP, Jalife J (1986) Dynamic interactions and mutual synchronization of sinoatrial node pacemaker cells. A mathematical model. Circ Res. 58(5):706-720. https://doi.org/10.1161/ 01.RES.58.5.706

47. Michaels DC, Matyas EP, Jalife J (1987) Mechanisms of sinoatrial pacemaker synchronization: a new hypothesis. Circ Res. 61(5): 704-714. https://doi.org/10.1161/01.RES.61.5.704

48. Mori Y, Fishman GI, Peskin CS (2008) Ephaptic conduction in a cardiac strand model with 3D electrodiffusion. Proc Natl Acad Sci. 105(17):6463-6468. https://doi.org/10.1073/pnas.0801089105

49. Ning F, Luo L, Ahmad S, Valli H, Jeevaratnam K, Wang T, Guzadhur L, Yang D, Fraser JA, Huang CLH, Ma A, Salvage SC (2016) The RyR2-P2328S mutation downregulates Nav1.5 producing arrhythmic substrate in murine ventricles. Pflugers Arch. 468(4):655-665. https://doi.org/10.1007/s00424-015-1750-0

50. Nowak MB, Greer-Short A, Wan X, Wu X, Deschênes I, Weinberg SH, Poelzing S (2020) Intercellular sodium regulates repolarization in cardiac tissue with sodium channel gain of function. Biophys J. 118(11):2829-2843. https://doi.org/10.1016/j.bpj.2020.04.014

51. Nowak MB, Poelzing S, Weinberg SH (2020) Mechanisms underlying age-associated manifestation of cardiac sodium channel gainof-function. J Mol Cell Cardiol. 153:60-71. https://doi.org/10. 1016/j.yjmcc.2020.12.008

52. Nygren A, Giles WR (2000) Mathematical simulation of slowing of cardiac conduction velocity by elevated extracellular $[\mathrm{K}+]$ in a human atrial strand. Ann Biomed Eng. 28(8):951-957. https://doi.org/ 10.1114/1.1308489

53. Parham WA, Mehdirad AA, Biermann KM, Fredman CS (2006) Hyperkalemia revisited. Texas Hear Inst J. 33(1):40-47 http:// www.ncbi.nlm.nih.gov/pubmed/16572868

54. Park DS, Cerrone M, Morley G, Vasquez C, Fowler S, Liu N, Bernstein SA, Liu FY, Zhang J, Rogers CS, Priori SG, Chinitz LA, Fishman GI (2015) Genetically engineered SCN5A mutant pig hearts exhibit conduction defects and arrhythmias. J Clin Invest. 125(1):403-412. https://doi.org/10.1172/JCI76919

55. Petitprez S, Zmoos A-F, Ogrodnik J, Balse E, Raad N, el-Haou S, Albesa M, Bittihn P, Luther S, Lehnart SE, Hatem SN, Coulombe A, Abriel H (2011) SAP97 and dystrophin macromolecular complexes determine two pools of cardiac sodium channels Nav1.5 in cardiomyocytes. Circ Res. 108(3):294-304. https://doi.org/10. 1161/CIRCRESAHA.110.228312

56. Raisch TB, Yanoff MS, Larsen TR et al (2018) Intercalated disk extracellular nanodomain expansion in patients with atrial fibrillation. Front Physiol 9(MAY):1-10. https://doi.org/10.3389/fphys. 2018.00398

57. Rhett JM, Ongstad EL, Jourdan J, Gourdie RG (2012) Cx43 associates with $\mathrm{Na}(\mathrm{v}) 1.5$ in the cardiomyocyte perinexus. J Membr Biol. 245(7):411-422. https://doi.org/10.1007/s00232-012-9465-z

58. Rhett JM, Gourdie RG (2012) The perinexus: a new feature of Cx43 gap junction organization. Hear Rhythm. 9(4):619-623. https://doi.org/10.1016/j.hrthm.2011.10.003

59. Rivera-Juárez A, Hernández-Romero I, Puertas C, Zhang-Wang S, Sánchez-Álamo B, Martins R, Figuera C, Guillem MS, Climent AM, Fernández-Avilés F, Tejedor A, Jalife J, Atienza F (2019) Clinical characteristics and electrophysiological mechanisms underlying Brugada ECG in patients with severe hyperkalemia. J Am Heart Assoc. 8(3):e010115. https://doi.org/10.1161/JAHA. 118.010115

60. Rohr S, Kucera JP, Fast VG, Kléber AG (1997) Paradoxical improvement of impulse conduction in cardiac tissue by partial cellular uncoupling. Science. 275(5301):841-844. https://doi.org/ 10.1126/science. 275.5301 .841

61. Shaw RM, Rudy Y (1997) Electrophysiologic effects of acute myocardial ischemia. Circ Res. 80(1):124-138. https://doi.org/10.1161/ 01.RES.80.1.124

62. Siegel A, Walton RM (2020) Hematology and Biochemistry of small mammals. In: Ferrets, Rabbits, and Rodents. Elsevier, pp 569-582. https://doi.org/10.1016/B978-0-323-48435-0.00039-3

63. Sperelakis N, Mann JE (1977) Evaluation of electric field changes in the cleft between excitable cells. J Theor Biol. 64(1):71-96. https://doi.org/10.1016/0022-5193(77)90114-x

64. Stein M, van Veen TAB, Hauer RNW, de Bakker JMT, van Rijen HVM (2011) A 50\% reduction of excitability but not of intercellular coupling affects conduction velocity restitution and activation delay in the mouse heart. PLoS One. 6(6):e20310. https://doi.org/10. 1371/journal.pone. 0020310

65. Swaminathan PD, Purohit A, Hund TJ, Anderson ME (2012) Calmodulin-Dependent protein kinase II: linking heart failure and arrhythmias. Circ Res. 110(12):1661-1677. https://doi.org/10. 1161/CIRCRESAHA.111.243956

66. Tsumoto K, Ashihara T, Haraguchi R, Nakazawa K, Kurachi Y (2014) Ischemia-related subcellular redistribution of sodium channels enhances the proarrhythmic effect of class I antiarrhythmic drugs: a simulation study. PLoS One. 9(10):e109271. https://doi. org/10.1371/journal.pone.0109271

67. Tsumoto K, Ashihara T, Naito N, Shimamoto T, Amano A, Kurata Y, Kurachi Y (2020) Specific decreasing of Na + channel expression on the lateral membrane of cardiomyocytes causes fatal arrhythmias in Brugada syndrome. Sci Rep. 10(1):19964. https:// doi.org/10.1038/s41598-020-76681-3

68. Veeraraghavan R, Salama ME, Poelzing S (2012) Interstitial volume modulates the conduction velocity-gap junction relationship. AJP Hear Circ Physiol. 302(1):H278-H286. https://doi.org/10. 1152/ajpheart.00868.2011

69. Veeraraghavan R, Hoeker GS, Alvarez-Laviada A, Hoagland D, Wan X, King DR, Sanchez-Alonso J, Chen C, Jourdan J, Isom LL, Deschenes I, Smyth JW, Gorelik J, Poelzing S, Gourdie RG (2018) The adhesion function of the sodium channel beta subunit ( 1 ) contributes to cardiac action potential propagation. Elife. 7. https://doi.org/10.7554/eLife.37610

70. Veeraraghavan R, Lin J, Hoeker GS, Keener JP, Gourdie RG, Poelzing S (2015) Sodium channels in the Cx43 gap junction perinexus may constitute a cardiac ephapse: an experimental and modeling study. Pflugers Arch. 467(10):2093-2105. https://doi. org/10.1007/s00424-014-1675-Z

71. Veeraraghavan R, Lin J, Keener JP, Gourdie R, Poelzing S (2016) Potassium channels in the $\mathrm{Cx} 43$ gap junction perinexus modulate ephaptic coupling: an experimental and modeling study. Pflugers Arch. 468(10):1651-1661. https://doi.org/10.1007/s00424-016$1861-2$

72. Warren M, Zaitsev AV (2017) CaMKII blockade, cardiac conduction, and arrhythmia. Cardiovasc Res. 113(14):1798-1799. https:// doi.org/10.1093/cvr/cvx199

73. Weinberg SH (2017) Ephaptic coupling rescues conduction failure in weakly coupled cardiac tissue with voltage-gated gap junctions. Chaos An Interdiscip J Nonlinear Sci. 27(9):093908. https://doi. org/10.1063/1.4999602

74. Weiss JN, Qu Z, Shivkumar K (2017) Electrophysiology of hypokalemia and hyperkalemia. Circ Arrhythmia Electrophysiol 10(3). https://doi.org/10.1161/CIRCEP.116.004667

Publisher's note Springer Nature remains neutral with regard to jurisdictional claims in published maps and institutional affiliations. 